\title{
COVID-19 Sudden Outbreak of Mystery Case Transmissions in Victoria, Australia, May-June 2021: Strong Evidence of Tropospheric Transport of Human Passaged Infective Virions from the Indian Epidemic
} \author{
Wainwright ${ }^{3}$ and N. Chandra Wickramasinghe ${ }^{3,6,8,9}$ \\ ${ }^{1}$ C.Y.O' Connor ERADE Village Foundation, Piara Waters, Perth, WA, Australia \\ ${ }^{2}$ Melville Analytics Pty Ltd, Melbourne, VIC, Australia \\ ${ }^{3}$ Centre for Astrobiology, University of Ruhuna, Matara, Sri Lanka \\ ${ }^{4}$ University Toronto Health Network, Toronto General Hospital, University of Toronto, Toronto, ON, Canada \\ ${ }^{5}$ School of Biological Sciences and Biotechnology, Murdoch University, WA, Australia \\ ${ }^{6}$ Institute for the Study of Panspermia and Astroeconomics, Gifu, Japan \\ ${ }^{7}$ The History of Chinese Science and Culture Foundation, Conway Hall, London, United Kingdom \\ ${ }^{8}$ University of Buckingham, Buckingham, United Kingdom \\ ${ }^{9}$ National Institute of Fundamental Studies, Kandy, Sri Lanka
}

Edward J. Steele ${ }^{1,2,3 *}$, Reginald M. Gorczynski ${ }^{4}$, Patrick Carnegie ${ }^{5}$, Gensuke Tokoro ${ }^{6}$, Daryl H. Wallis ${ }^{6}$, Robert Temple ${ }^{7}$, Milton $^{3}$

*Corresponding author: Edward J. Steele, C.Y.O’ Connor ERADE Village Foundation, Piara Waters, Perth, WA, Australia; E-mail: e.j.steele@bigpond.com

Received: June 20, 2021; Accepted: July 05, 2021; Published: July 12, 2021

\begin{abstract}
A sudden yet very small outbreak of COVID-19 mystery community transmissions occurred in a defined arc across the inner Western and outer Northern suburbs of Melbourne in May-June 2021. An infection zone that could be $1000 \mathrm{~km}^{2}$ in size. These sudden outbreaks of genuine mystery cases could not be traced to any direct infected contacts nor could they be directly genomically linked to any known infection clusters (e.g. among infected international travellers in hotel quarantine). In response the Government of Victoria on the recommendation of the Chief Medical Officer and the Victorian Department of Health locked down the entire State of Victoria in an extreme Stage 4 emergency. As a consequence, large numbers of PCR COVID-19 tests on oro-nasal swabs were conducted $(>30,000$ per day at peak) and all positives quarantined at home, a directive enforced by police and in some cases the Australian Army. Citizens were neither allowed to leave Melbourne nor from Victoria to any other State of Australia. Contact tracing was conducted on a very large scale by teams of experienced tracers. Several sudden mystery outbreaks continued to occur despite the lock-down on people movements. This included restriction of numbers of visitors at homes, crowd-size limitations, curtailment of sporting events, school closures, mandatory mask wearing, and personal tracking of all individuals in shops and supermarkets (via a personal "QR" digital tracking system linked to mobile phones or via written personal contact statements at store or shop entry). Many of the COVID-19 variants of concern (PANGO classification) were clearly mature human-passaged virions, many of which have been identified in the current and very large $2^{\text {nd }}$ Wave Indian epidemic. We show here there is plausible strong evidence that a heterogeneous set of these "Indian" variants may have been transported by prevailing tropospheric global wind systems via the Indian Ocean and Southern Ocean (Roaring Forties West to East on the $40^{\circ} \mathrm{S}$ Latitude line) to Victoria, Australia. There is much precedent for such global wind transportations in the history of past Influenza virus pandemics in the last 100 years and the present observations relating to COVID-19 events in Australia are discussed in that context.
\end{abstract}

\section{Introduction}

A cool and objective scientific understanding the origins and global spread of the COVID-19 virus is the most pressing issue of our time. The multifactorial evidence that we have assembled through 2020 is fully consistent with COVID-19 arriving first via a looselyheld life-bearing carbonaceous cometary bolide that dispersed its viral cargo in the stratosphere on the $40^{\circ} \mathrm{N}$ Latitude line over Jilin in North East China on the night of October 112019 [1-3]. A long series of air-sampling experiments carried out in the stratosphere over the past 20 years have revealed unequivocal evidence of biological entities ranging in size from tens of nanometres, identifiable as virions, to several microns corresponding to bacteria at heights of up to 41 $\mathrm{km}[4,5]$. More recently, Grebennikova et al. have identified by PCR techniques several bacterial species on the outside of the International Space Station (orbiting at a height of $400 \mathrm{~km}$ ) which are most plausibly of cometary origin [6]. A variable population of bacteria and viruses in the stratosphere thus appears to have a firm empirical basis, and is moreover consistent with the theory of cometary panspermia for which there is now a formidable body of evidence $[7,8]$. 
Edward J. Steele (2021) COVID-19 Sudden Outbreak of Mystery Case Transmissions in Victoria, Australia, May-June 2021: Strong Evidence of Tropospheric Transport of Human Passaged Infective Virions from the Indian Epidemic

A critical evaluation of all the relevant evidence suggests the causative virus of the COVID-19 pandemic could not have come from an infected bat or pangolin to infect all of the central region of China around Wuhan city and Hubei province on the scale that was witnessed in Nov 2019-Jan 2020 [2,9]. In our opinion, guided by the relevant evidence and observations of many similar instances of suddenly emergent pandemics throughout history [10], this pandemic is entirely natural which is by no means unique. It represents a natural phenomenon consistent with the emerging paradigm that life is an all pervasive cosmic phenomenon [10-12]. It is unrelated to putative explanations based on non-scientific ad hoc human-induced conspiracy theories - such as those currently in vogue in the popular press e.g. "Wuhan Virus Lab Leak" theories. It cannot be emphasised too strongly that all such explanations are non-scientific. They require too many ad hoc assumptions, many incoherent and contradictory, when rationally examined in the light of all the unfolding temporal key evidence. The appropriate scientific domains in which the relevant data must be addressed and analysed for this pandemic must of necessity include immunology, genetics, epidemiology, astrobiology and atmospheric physics. The group of scientists that we represent has been tracking, analysing, explaining as well as predicting with accuracy the course of this suddenly emergent virus disease from its origin and early spread in Wuhan in late November 2019 through January 2020, following in our view the arrival at the Earth of a putative life-bearing cometary bolide $[1,3]$. We then analysed the early evidence against the standard explanation of global infection-driven solely by personto-person (P-to-P) transfer of the COVID-19 virus [13]. The longdistance transfer of infection after the initial Wuhan strike to other far-flung global regions occurred primarily not by P-to-P transfer but via upper level tropospheric/stratospheric jet streams on a $40^{\circ}-60^{\circ}$ $\mathrm{N}$ latitude band from East to West [14]. This process combined with more localised lower-level tropospheric wind systems (West-to-East) explains much of the unfolding data in the early weeks of the pandemic. This includes the otherwise mysterious transport across the Pacific Ocean of the L haplotype of the Wuhan-plumed P-to-P virus to infect the Grand Princess cruise ship off San Francisco [3].

The pandemic next appeared to move into lower - level Atlantic Ocean prevailing wind systems and thence into the Southern Hemisphere [15]. During this early period, up to May 2020, many ships at sea became engaged with sudden and seemingly mysterious COVID-19 outbreaks: cruise ships (Diamond Princess, Westerdam Grand Princess), aircraft carriers (USS Theodore Roosevelt, the French Navy's Charles de Gaulle), various fishing trawlers and live animal transportation ships $[9,16]$. Wherever these 'ship at sea' strikes could be cleanly analysed it became evident that all such outbreaks are best understood as mid-ocean depositions of COVID-19 virions with all the tell-tale signs of aerial pathogenic attack $[9,16]$. Moreover, sudden strikes on isolated islands such as Sri Lanka that had flat-lined in COVID-19 case incidence all year (2020) and then suddenly became engaged in a few days (Oct 4-6, 2020) with over a thousand active cases are difficult to understand in terms of traditional P-to-P spreads considering the associated minimum incubation time between transfers of infections of about one week [3,17]. Another remarkable incident of a similar kind is the isolated Chilean military base in
Antartica, thousands of kilometres from civilisation that became suddenly engaged late December 2020 [3]. A cool objective assessment of all these types of striking sudden COVID-19 outbreaks are inconsistent with traditional P-to-P infectious disease epidemiology, but entirely consistent with transportation via tropospheric winds and precipitation (rain) bringing the viral-laden clouds to ground. In this way we can explain the sudden and simultaneous appearance of sporadic mass infections in widely separated geographical locations that are mutually isolated, and thus cannot be cross-infecting one another by a P-to-P spread process. The intensity of each outbreak in any given geographical zone depends only upon viral density at infall, and the exposed susceptible human population density in that area. The viral density detected at ground level is predicted to be quite patchy, on scales determined by the turbulence patterns caused by thermal fluctuations determined by local heat sources.

The modern tendency to invoke the ad hoc concepts of super spreaders, asymptomatic carriers or "stranger-to-stranger" spread to explain any baffling aspects of the pandemic is a desperate attempt to maintain the status quo of the terrestrial origin of the virus and its P-to-P spread. It is interesting to recall that this is strikingly reminiscent of the Ptolemaic epicycles that were invoked in the last days of the Copernican revolution (Supplementary Information). It was the multiplication of such epicycles that finally led to the rejection of the Ptolemaic Earthcentred universe. Whether we have now come anywhere near this critical point in the story of COVID-19 epidemiology is left to be seen. Through 2020 we analysed the genetics of adaption of the COVID-19 virus in the first few months of the pandemic in 2020 at clear explosive hotspot locations (Wuhan, New York City, US West Coast) and defined the initial ( $a$ initio) haplotype sorting process used by all respiratory epithelial lining cells in the innate -immune driven host -parasite relationship in the first 24-48 hrs of infection - APOBEC and ADAR deaminase-driven ribo-switching of a common set of COVID-19 haplotypes. These are best understood as co-ordinated single nucleotide variant (SNV) changes consistent with successful effective replicative RNA secondary structures $[9,18]$. This is discussed further in 'Haplotype Analysis' in Materials and Methods.

In a review of all the relevant key evidence the most parsimonious explanation seems to be that COVID-19 came from space [2,3], just as have many other similar suddenly emergent pandemics past and recent: such as the Spanish Flu 1918-1919 and the other pandemics that punctuate history over millennia, and in particular over the best documented period over the past 100 years spanning the $20^{\text {th }}$ and $21^{\text {st }}$ centuries [10-12]. In this report we now critically evaluate the publicly available infection and COVID-19 genomic data for the sudden, yet small, outbreak of COVID-19 cases in Victoria, Australia in May - June 2021. Many of the initiating cases prior to P-to-P spreading within a local cluster are genuine mystery/community transmissions that have still not been resolved as this paper was submitted (as June 19 2021) - either by contact tracing or by genomic sequencing matching with already known clusters in the epidemic target zone. Given the global isolation of Australia as an island continent, and the further isolation of the State of Victoria, taken together with the stringent quarantine and isolation regulations combined with diligent contact tracing that have been in place, we have here a remarkable setting for a controlled experiment for 
Edward J. Steele (2021) COVID-19 Sudden Outbreak of Mystery Case Transmissions in Victoria, Australia, May-June 2021: Strong Evidence of Tropospheric Transport of Human Passaged Infective Virions from the Indian Epidemic

\section{A. India}

Statistics

\section{New cases and deaths}

From JUU CSSE COVio-19 Data · Last updahod: 2 days ago

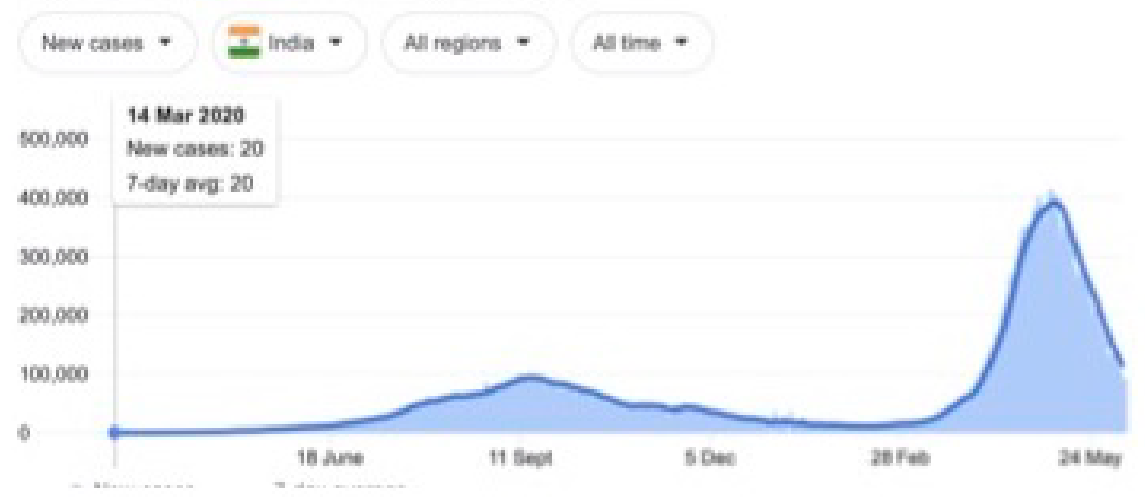

\section{B. United Kingdom}

\section{Statistics}

\section{New cases and deaths}

From atu cSSE COnD-19 Data - Last updated: 2 days ago

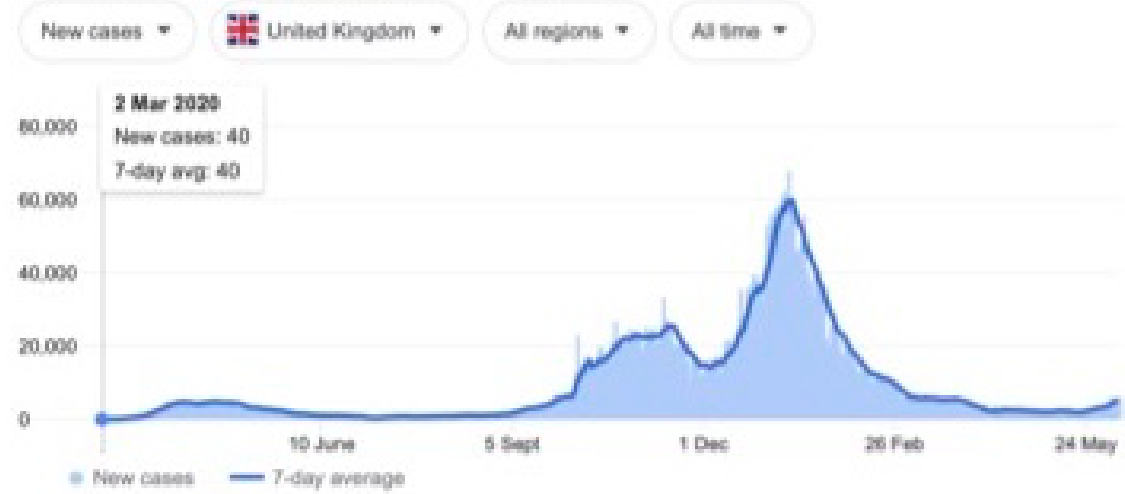

\section{Australia}

\section{Statistics}

New cases and deaths

From Wriceda - Last updated. to nours ago

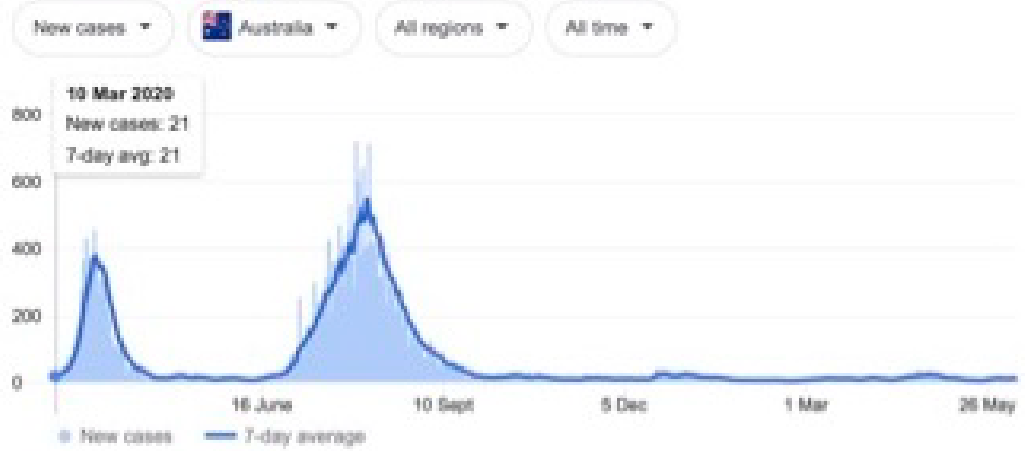

Figure 1: Magnitude and timing of the COVID-19 epidemics in Inda, United Kingdom amd Australia during 2020 and 2021

Google: "Coronavirus disease statistics"URL is https:/www.google.com.au/search?hl=en\&ei=vWxyX7ipM4-m9QP18If4CQ\&q=Coronavirus+disease+statistics\&oq=Coronavirus+disease+s tatistics\&gs_lcp=CgZwc3ktYWIQAzICCAAyAggAOgQIABBHOgcIABCxAxBDOgQIABBDULZUWPh1YJF7aABwAXgAgAH2AYgBvA6SAQYwLjEwLjGYAQCgAQGqAQdnd3Mtd216yAE GwAEB\&sclient=psy-ab\&ved=0ahUKEwj4-47e-4zsAhUPU30KHXX4AZ8Q4dUDCAw\&uact=5

This gives you the "Australia" dashboard (from there you can choose your country in the menu bar scroll). 
testing transmission models of the COVID-19 pandemic. As seen in Figure 1 all the case numbers in Australia are minuscule in comparison with the Northern Hemisphere infected zones (and see Supplementary Information). Further advantages in the situation in Victoria include the scale of mass PCR COVID-19 testing ( $\geq 30,000$ per day, Figure 2 ); and a strictly policed social distancing/mask covering with Stage 3 and Stage 4 lock down regulations enforced in Victoria with the deployment of police and sometimes the army. The available data in the public domain allows scientific conclusions not as easily derived for the Northern Hemisphere infected zones, where the disease is of far greater intensity and wider geographic extent (two to four orders of magnitude greater than the greater metropolitan area of Melbourne, Victoria - this has, however, had well over 90\% of all COVID-19 cases in Australia in 2020 and 2021 c.f. Figure 1 and URL link).

There are two general tropospheric viral-laden in-fall hypotheses that could serve to explain the patterns in these mystery infection data. They could operate together, or one or other may prevail in quantitative terms.

The two possibilities are:

A. The sudden outbreaks are due to precipitation bringing down virus-laden cometary dust in an arc around inner-outer Melbourne (West-North, approximately $1000 \mathrm{Km}^{2}$ ) thus contaminating the environment and causing spot mystery infections of SARS-CoV-2 respiratory disease (generating simple haplotype variants $a b$ initio, as Steele and Lindley [18]).

B. The sudden outbreaks are caused by the same precipitation (rain) bringing down human passaged virions transported in global wind circulation from Northern Hemisphere infected zones, in particular from the Indian outbreaks.

The most likely source, in our view, would be the putative and massive viral plume over India of virions which have already "gone through" human passage (P-to-P), and thus showing substantially modified genomic sequences as multiple P-to-P products from the early ab initio haplotype sequences These were discussed, using data from the first three months of 2020, for haplotype diversification between Wuhan and New York City $[9,18]$.
Here we assemble the evidence that strongly supports hypothesis $B$, that all the community transmission 'mystery cases' in the Victorian epidemic in May - June 2020 may have been caused by a range of Indian human-passaged viruses delivered to Victoria, Australia, from elsewhere, most likely via the Indian subcontinent viral plume via tropospheric wind systems. This conclusion is not inconsistent with low level tropospheric prevailing wind systems spreading viral pandemics in the recent past via non P-to-P processes on scale [10]. Many striking non P-to-P spreading events like this were reviewed over 30 years ago by Hammond et al. [19].

\section{Materials and Methods}

\section{Publicly Available Data Resources}

\section{a. GenBank/NCBI Virus db}

For full length COVID-19 genomic sequences and their haplotype analysis against the Wuhan Hu-1 29903 nt long RNA reference sequence (NC_045512.2) all Genbank Accession sequence data were obtained and aligned (multiple sequence alignments) using the NCBI Virus database and alignment tools. This publicly accessible site is hosted at The National Center for Biotechnology Information (NCBI) at the National Institutes of Health (NIH), Bethesda, Maryland, USA, which curates SARS-CoV-2 sequences at https://www.ncbi.nlm.nih. gov/sars-cov-2/\#nucleotide-sequences

\section{b. Epidemiological Information}

This is from that published daily by the national newspaper The Australian and other information from Melbourne's Herald-Sun newspaper. All specific details are referenced or expanded on in the Supplementary Information. Other data for background long term cross checking can be access at The Victorian Department of Health website https://www.dhhs.vic.gov.au/victorian-coronavirus-covid-19data

\section{c. Weather Information}

This was from The Australian Bureau of Meteorology (BOM) and also news reports through April and May 2021

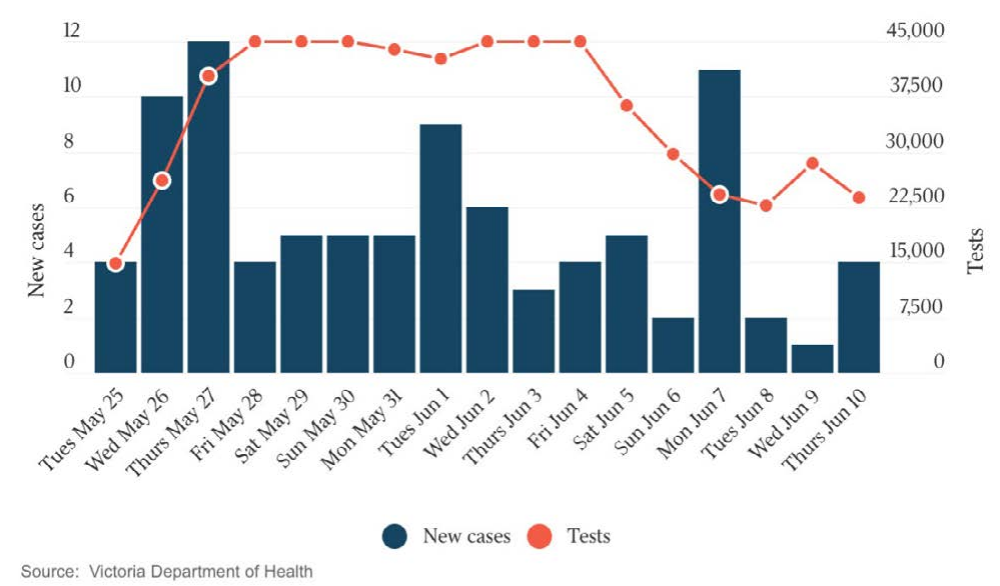

Figure 2: New Cases per Day and Total PCR Tests per Day in Victoria. The Australian 10 June 2021. Hard Stage 4 lockdown across entire state of Victoria introduced on May 27. 
Edward J. Steele (2021) COVID-19 Sudden Outbreak of Mystery Case Transmissions in Victoria, Australia, May-June 2021: Strong Evidence of Tropospheric Transport of Human Passaged Infective Virions from the Indian Epidemic

http://www.bom.gov.au/climate/dwo/202105/html/ IDCJDW3050.202105.shtml

\section{Haplotype Analysis}

The haplotype approach to COVID-19 sequence diversification [18] differs from the PANGO classification system which uses a phylogenetic approach which generates putative person-to-person (P-to-P) lineages, clusters and clades [20,21]. The ab initio haplotypesort/selection explanation, during first infection of respiratory epithelial cells in the first Host-Parasite encounter - by viral-laden meteorite tropospheric dust - is a better primary explanation of the APOBEC/ADAR-driven deaminase ribo-switching process and informs classification of sequences through molecular understanding based on variant RNA secondary structures. In the first three months of the pandemic this ribo-switching haplotype sorting and quasi-species selection process operates in the first subject infected host [22,23]. This generates, in our view, a range of quasi-species and then hostparasite selection allows successful emergence of a replicative 29903 nt long RNA secondary structure haplotype in that subject host (Steele and Lindley 2020 [18] Table 1). The PANGO variants published in The Australian newspaper (Saturday 5 June 2021) which are of concern to the Victorian Department of Health (Figure 3) have been assigned haplotypes using these markers (Table 2).

Criteria for a SNV in the Coding Regions (CDS) Classed as Conserved, Benign, Radical (Table 2) - as defined in Steele and Lindley (2020) [18]

Conserved: These are synonymous SNVs or a SNV change leading to the same amino acid (AA) functional class. Benign: These are AA changes which are Polar $<->$ NonPolar, Acid $<->$ Polar, or Basic $<->$ Polar. Radicle: These are AA changes Acid $<->$ NonPolar, Basic $<->$ NonPolar, Acidic <-> Basic.

\section{Multiple PANGO Sequences Used to Determine Haplotypes as Shown in Table 2}

Shown in Table 3 are the GenBank accession numbers of many of the PANGO variants of concern in Victoria from the NCBI Virus website for the haplotype analysis in the Melbourne, Victoria outbreak of mystery cases in May-June 2021- all haplotyped in multiple alignments v Hu-1 (NC_045512).

Among a Set of the Same "PANGO Designated Variants"

Table 1: Putative Ab Initio Haplotypes and Main Sites Defining COVID-19 Common Strain Variants in first 3 months of the pandemic (Jan-Mar 2020).

\begin{tabular}{|c|c|c|c|c|c|c|c|c|c|c|c|c|c|c|c|c|c|c|c|}
\hline Hor & $\begin{array}{c}\text { Muclsss-s } \\
\text { sutR } \\
\text { p.241 }\end{array}$ & $\begin{array}{l}\text { PoNore } \\
\text { Throllo } \\
\text { p. 10so }\end{array}$ & $\begin{array}{c}\text { SW } \\
\text { Proopto } \\
\text { p.3037 }\end{array}$ & $\begin{array}{l}\text { Pofilon? } \\
\text { noofle } \\
\text { p.116s }\end{array}$ & $\begin{array}{c}\text { SW } \\
\text { Theorthe } \\
\text { p.TS40 }\end{array}$ & $\begin{array}{c}\text { ShN } \\
\text { Sorosar } \\
\text { parnz }\end{array}$ & $\begin{array}{l}\text { Nernoolions } \\
\text { Leuepthe } \\
\text { p.1100s/as }\end{array}$ & $\begin{array}{l}\text { NonPeoNenP } \\
\text { Proeslos } \\
\text { p.1<egs }\end{array}$ & $\begin{array}{c}5 \mathrm{~N} \\
\text { Trothr } \\
\text { p.seg-n }\end{array}$ & $\begin{array}{c}\text { Nonpeofion? } \\
\text { Proolev } \\
\text { P17747 }\end{array}$ & $\begin{array}{l}\text { pop } \\
\text { Tyroogen } \\
\text { p17ass }\end{array}$ & 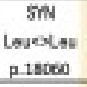 & $\begin{array}{c}\text { SW } \\
\text { Apporiey } \\
\text { p.1asss }\end{array}$ & $\begin{array}{l}\text { Plop } \\
\text { Sorofien } \\
\text { p.22min }\end{array}$ & $\begin{array}{c}\text { Sw } \\
\text { Gneogh } \\
\text { p.23401 }\end{array}$ & 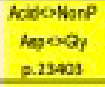 & $\begin{array}{l}\text { Potbenic } \\
\text { Ginertis } \\
\text { p.2sses }\end{array}$ & $\begin{array}{l}\text { Prowsep } \\
\text { Lovoser } \\
\text { p.2rit4 }\end{array}$ & 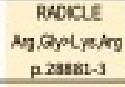 \\
\hline L $\{$ Hall & c & c & c & A & $T$ & c & 0 & c & 6 & c & A & c & c & 6 & 0 & A & 6 & $T$ & 666 \\
\hline In & c & c & C & A & $T$ & c & $T$ & C & 6 & c & A & c & c & 6 & 0 & A & 6 & $T$ & GQ6 \\
\hline L. $241 \mathrm{a}$ & $T$ & $T$ & $T$ & A & $T$ & c & G & $T$ & G & c & A & C & c & G & G & G & $T$ & $T$ & GGG \\
\hline L.241b & $T$ & T & c & A & $T$ & c & G & $T$ & G & c & A & c & c & G & G & G & $T$ & T & GGG \\
\hline L-241t & T & C & $T$ & A & $T$ & C & 0 & $T$ & 6 & c & A & c & C & 6 & 0 & 6 & $T$ & T & $G G 6$ \\
\hline$L-241 d \&$ & T & $T$ & T & A & $T$ & C & 0 & C & 6 & c & A & c & C & 6 & 0 & 6 & T & $\top$ & $G 66$ \\
\hline L.2410 & $T$ & C & C & A & $T$ & c & G & $\mathrm{T}$ & G & c & $A$ & c & c & G & G & G & T & T & GGG \\
\hline L.241f & T & C & T & A & $T$ & c & G & T & G & c & A & c & c & G & G & G & G & T & GGG \\
\hline เ-24ษ. 1 & T & C & T & A & $T$ & c & 6 & $T$ & 6 & c & A & c & c & 6 & 0 & 6 & $c$ & $T$ & AAC \\
\hline $1-2619$ & $T$ & c & C & A & $T$ & c & 0 & $T$ & 0 & c & A & c & c & 6 & 0 & 0 & 6 & $T$ & 666 \\
\hline s & C & C & C & A & $T$ & $T$ & G & c & G & c & A & c & c & G & G & A & G & C & GGG \\
\hline Sa & C & C & C & A & T & $T$ & G & C & G & $\mathrm{T}$ & G & T & c & G & G & A & G & C & GGG \\
\hline so & c & c & c & A & T & $T$ & 0 & c & 6 & c & A & c & C & 6 & 0 & A & 6 & $\mathrm{c}$ & 696 \\
\hline Ss & c & c & c & A & $T$ & $T$ & 0 & c & 6 & c & A & c & c & 6 & 0 & A & 6 & c & 666 \\
\hline
\end{tabular}

\begin{tabular}{|c|c|c|c|}
\hline \multicolumn{4}{|c|}{$\begin{array}{l}\text { VICTORIA'S OUTBREAK } \\
67^{\text {community-transmission cases }} \text { CORO }\end{array}$} \\
\hline \multirow{2}{*}{$\begin{array}{l}\text { O/ in total since 'Wollert man' } \\
\text { returned to Victoria from hotel } \\
\text { quarantine in South Australia. }\end{array}$} & & Pango lineage & Earliest samples \\
\hline & \multicolumn{3}{|c|}{ VARIANTS OF CONCERN } \\
\hline \multirow{2}{*}{$\begin{array}{l}60 \text { cases of the Kappa B.1.617.1 } \\
\text { strain, including one of the four } \\
\text { new cases announced on Friday. }\end{array}$} & Alpha & B.1.1.7 & 求 UK Sep 2020 \\
\hline & Beta & B.1.351 & South Africa May 2020 \\
\hline \multirow{2}{*}{ 64 cases } & Gamma & P.1 & 2 Brazil Nov 2020 \\
\hline & Delta & B.1.617.2 & India Oct 2020 \\
\hline \multirow{8}{*}{$\begin{array}{l}7 \text { cases of the Delta B.1.617.2 strain: } \\
\text { the family of four who holidayed } \\
\text { on the NSW south coast last month } \\
\text { and a family of three, two parents and } \\
\text { a Year } 5 \text { child, whose cases were } \\
\text { announced on Friday. }\end{array}$} & \multicolumn{3}{|c|}{ VARIANTS OF INTEREST } \\
\hline & Epsilon & B.1.427/B.1.429 & $\triangleq$ US Mar 2020 \\
\hline & Zeta & P. 2 & (2) Brazil Apr 2020 \\
\hline & Eta & B.1.525 & Multiple Dec 2020 \\
\hline & Theta & P. 3 & Philippines Jan 2021 \\
\hline & lota & B. 1526 & $\approx$ US Nov 2020 \\
\hline & Kappa & B.1.617.1 & India Oct 2020 \\
\hline & & & Source: พно \\
\hline
\end{tabular}

Figure 3: The Australian Saturday 5 June 2021. 
Edward J. Steele (2021) COVID-19 Sudden Outbreak of Mystery Case Transmissions in Victoria, Australia, May-June 2021: Strong Evidence of Tropospheric Transport of Human Passaged Infective Virions from the Indian Epidemic

Table 2: PANGO variants of COVID-19 of interest and concern in Melbourne, Victoria outbreak of mystery cases in May-June 2021

\begin{tabular}{|c|c|c|c|c|c|c|c|c|c|c|c|c|c|}
\hline \multirow[b]{3}{*}{ PANGO Variant } & \multirow{3}{*}{$\begin{array}{l}\text { Steele and Lindley } \\
\text { A } \text { Initio HAP seq }\end{array}$} & \multicolumn{10}{|c|}{ Numbers of additional variations accrued on top of S\&L HAP sequence when aligned against Hu-1 } & \multirow{3}{*}{ Total } & \multirow{3}{*}{$\begin{array}{l}\text { From } A b \text { lnitio } \\
\text { number putative } \\
\text { P-to-P transfers? }\end{array}$} \\
\hline & & $5^{\prime}$ UTR & 5' UTR & 3' UTR & 3' UTR & $\begin{array}{l}\text { Non- } \\
\text { CDS }\end{array}$ & $\begin{array}{l}\text { Non- } \\
\text { CDS }\end{array}$ & \multicolumn{4}{|c|}{ SNV CDS variants recorded as : } & & \\
\hline & & SNV & Indel & SNV & Indel & SNV & Indel & Conserved & Benign & Radical & In-frame Indel & & \\
\hline B.1.1.7 & L241f.1 & 0 & 0 & 0 & 0 & 0 & 0 & 7 & 3 & 6 & 1 to 3 & $17-19$ & 4 \\
\hline B.1.351 & L241a & 1 & 0 & 0 & 0 & 0 & 0 & 5 & 3 & 3 & 2 & 14 & 3 or 4 \\
\hline P.1 & L241f.1 & 0 & 0 & 2 & 0 & 0 & 1 & 11 & 9 & 2 & 1 & 26 & 5 or 6 \\
\hline B.1.617.2 & L24lf & 1 & 0 & 1 & 0 & 0 & 1 & 6 & 8 & 4 & 1 & 22 & 4 or 5 \\
\hline B.1.427/B.1.429 & L241a & 0 & 0 & 0 & 0 & 1 & 0 & 3 & 3 & 1 & 0 & 8 & 2 \\
\hline P. 2 & $\mathrm{Nd}$ & $\mathrm{Nd}$ & $\mathrm{Nd}$ & $\mathrm{Nd}$ & $\mathrm{Nd}$ & $\mathrm{Nd}$ & $\mathrm{Nd}$ & $\mathrm{Nd}$ & $\mathrm{Nd}$ & $\mathrm{Nd}$ & $\mathrm{Nd}$ & $\mathrm{Nd}$ & $\mathrm{Nd}$ \\
\hline B.1.525 & L241f & 0 & 0 & 0 & 1 & 1 & 0 & 18 & 5 & 1 & 4 & 30 & 6 or 7 \\
\hline P.3 & $\mathrm{Nd}$ & $\mathrm{Nd}$ & $\mathrm{Nd}$ & $\mathrm{Nd}$ & $\mathrm{Nd}$ & $\mathrm{Nd}$ & $\mathrm{Nd}$ & $\mathrm{Nd}$ & $\mathrm{Nd}$ & $\mathrm{Nd}$ & $\mathrm{Nd}$ & $\mathrm{Nd}$ & $\mathrm{Nd}$ \\
\hline B.1.526 & L241a & 0 & 0 & 0 & 0 & 0 & 1 & 7 & 5 & 1 & 1 & 15 & 3 to 4 \\
\hline B.1.617.1 & L241f & 1 & 0 & 1 & 0 & 0 & 1 & 5 & 7 & 5 & 0 & 17 & 3 or 4 \\
\hline
\end{tabular}

The PANGO variants from The Weekend Australian June 5-6 2021.

\section{There Will be Variable Sites - that is "Not All PANGOS are Identical"}

It is important to understand that when newly isolated COVID-19 genomic sequences are assigned a PANGO variant/lineage label, all PANGO variants with that label are not necessarily identical. Human passaged (P-to-P) will introduce further new variable sites within that haplotypic framework. For example in a multiple alignment against the Hu-1 reference of six B.1.617.2 variants (MZ318750, MZ318917, MZ320553, MZ317762, MZ318262, MZ318150) the number of nonhaplotypic shared sites above the 22 listed in Table 2 for B.1.617.2, there are 49 other sites that can vary. A similar pattern like this applies to sets of the other PANGO haplotypes in Table 2 aligned against $\mathrm{Hu}$ 1. Thus the statement that a freshly isolated sequence "has a particular PANGO variant sequence (i.e. haplotype) should not be taken to mean all members of that variant are identical as APOBEC/ADAR-driven variation at $\mathrm{P}$-to-P transfers ensures most will be not identical. Most of these differences (>95\%) result in conserved or benign AA changes i.e. there is considerable sequence conservation at the protein level due to Darwinian purifying selection (e.g. in the six B.1.617.2 sequences discussed above 48 of the 49 variable sites are conserved or benign as defined).

\section{Estimates of P-to-P Transfers (Table 2)}

It should be noted here that the estimates of the numbers of putative P-to-P transfers since ab initio creation in the first infection from raw meteorite dust-derived virus, is based on conservative estimates from the observations in the Wuhan (Jan 2020) and New York City (Mar 2020) hotspot zones [18].

\section{Results and Discussion}

To focus on the relevant geographical infected Melbourne region, Figures 4A and 4B show Google Maps of the West-North Melbourne arc where the great majority of waste water catchment COVID-19 fragment detections have been found (April to early May 2021, Supplementary Information) and where the suddenly emergent mystery case-generated clusters of COVID-19 infections have later
Table 3: Gen Bank accession numbers of all PANGO sequences multiply aligned for haplotype assignment.

\begin{tabular}{|c|c|c|c|}
\hline Accession & $\begin{array}{c}\text { Collect } \\
2021\end{array}$ & Geo Location & PANGO \\
\hline MZ310552 & $04-12$ & India & B.1.1.7 \\
\hline MZ310908 & $05-05$ & USA.SC. Lancaster & B.1.1.7 \\
\hline MZ317817 & $05-10$ & USA, Rhode Island & B.1.351 \\
\hline MZ317890 & $02-02$ & India & B.1.351 \\
\hline MZ317892 & $02-02$ & India & B. 1.351 \\
\hline MZ318331 & $04-15$ & USA, North Carolina & B. 1.351 \\
\hline MZ311471 & $05-14$ & USA. Mass & P.1 \\
\hline MZ311478 & 05-19 & USA. New Hampshire & P.1 \\
\hline MZ317762 & 05-04 & USA Mass & B.1.617.2 \\
\hline MZ318159 & $04-10$ & India & B.1.617.2 \\
\hline MZ318262 & $04-30$ & USA & B.1.617.2 \\
\hline MZ318750 & $05-11$ & USA Texas & B.1.617.2 \\
\hline MZ318817 & 05-09 & USA Arkansas & B. 1.517 .2 \\
\hline MZ318917 & 05-09 & USA New Jersey & B.1.617.2 \\
\hline MZ310942 & $05-20$ & USA. Mass & B.1.617.2 \\
\hline MZ304709 & $05-08$ & USA. California & B.1.617.2 \\
\hline MZ317766 & $05-03$ & USA, Mass & B.1.427 \\
\hline MZ317895 & $04-01$ & Germany, Frankfurt & B. 1.427 \\
\hline MZ317896 & $01-14$ & Germany, Frankfurt & B.1.429 \\
\hline MZ318827 & $05-10$ & USA, California & B.1.429 \\
\hline MZ318829 & $05-11$ & USA, Texas & B. 1.427 \\
\hline \multicolumn{4}{|l|}{ P. $2-\mathrm{Nd}$} \\
\hline MZ317699 & $2021-05$ & USA Virginia & B. 1.525 \\
\hline MZ321539 & $05-12$ & USA Mass & B. 1.525 \\
\hline \multicolumn{4}{|l|}{ P.3-Nd } \\
\hline MZ311490 & $05-14$ & USA. New Hampshire & B.1.526 \\
\hline MZ311497 & $05-20$ & Rhode Island & B.1.526 \\
\hline MZ310590 & $03-17$ & India & B.1.617.1 \\
\hline MZ310588 & $02-12$ & India & B.1.617.1 \\
\hline
\end{tabular}

been found (below and Supplementary Information). A conservative estimate of the size of the region could be at least $1000 \mathrm{Km}^{2}$, stretching from Altona/Maidstone in Melbourne's South West to the northern Whittlesea local government area (LGA) in which the suburb of Wollert is on the southern edge. The distance from Altona to the northern edge of Whittlesea LGA is at least $30 \mathrm{Km}$. 


\section{Weather in Melbourne and Environs through April into May 2021}

There was significant April rain in greater Melbourne, usually at night and cold, on $9^{\text {th }}(6.2 \mathrm{~mm}), 10^{\text {th }}(0.2 \mathrm{~mm}), 11^{\text {th }}(3.4 \mathrm{~mm}), 12^{\text {th }}(10$ $\mathrm{mm}), 13^{\text {th }}(0.6 \mathrm{~mm}), 16^{\text {th }}(1 \mathrm{~mm}), 21^{\text {st }}(10.4 \mathrm{~mm}), 23^{\text {rd }}(0.4 \mathrm{~mm}), 25^{\text {th }}$ $(2.6 \mathrm{~mm}), 26^{\text {th }}(1.2 \mathrm{~mm}), 27^{\text {th }}(0.6 \mathrm{~mm}), 28^{\text {th }}(0.4 \mathrm{~mm})$; then again further rains well into May and June including severe flooding in the same regions covered in the Google Maps above. Precipitation coming up from the Southern Ocean in a SW to E direction (the typical prevailing way the winter weather visits Victoria) would be a necessary pre-condition for any tropospheric clouds of COVID-19 virion dust-associated particles to be brought to ground.

\section{PCR COVID-19 Fragments Detected in Waste-Water Catchments Prior to Sudden Outbreak}

The West-North arc and range of these detections is specifically covered in the Supplementary Information. They occurred during a period when no COVID-19 cases had been detected for many weeks (prior to May 11). These significant PCR detection signals occurred in late April early May before 'Wollert Man' the putative infective P-to-P trigger for the entire outbreak (see below and Supplementary Information) left the Adelaide quarantine hotel (May 4) and cover the same environment footprint where all the key putative mystery cases have been reported or deduced to have emerged. Thus, significant environmental contamination with COVID-19 genomes appears to have occurred and are manifest in waste-water catchment reservoirs in the W-N arc under discussion and analysis - it stretches incredulity that all the PCR fragments signals, in the face of massive dilution factors, are due to undetected high-rate urine shedders of COVID-19 virions by undetected asymptomatic infected subjects. The maps in Figures $4 \mathrm{~A}$ and $4 \mathrm{~B}$ can assist in visualising this COVID-19 fragment footprint in association with Supplementary Information.

\section{Analysis of Key Mystery Cases and Clusters}

The caveats to this analysis are the absence of meta-data (ethnicity, clinical status, exact likely locations at infection) and the non-availability of exact COVID-19 genomic sequence(s) apart from muted PANGO variant of the infected subjects as well as considerable mis-information about each case in the mass media. There is only limited knowledge of the genomic sequence (shown in Figure 3) some are either Indian variant kappa (B.1.617.1) or delta (B.1.617.2) as assigned below. When it was neither variant that was acknowledged in the press release we can only deduce that in that particular mystery case the sequence was "one of concern" as summarised in Figure 3 and Table 2. All the key public information around the origin of each mystery cluster is provided in the Supplementary Information for the reader to independently weigh up the evidence pro and con. In our considered view every case in the list below is a real mystery community transmission- no definitive genomic links nor $P$-to- $P$ contact links with any other cluster. There has been considerable speculation in the mass media with state-wide (and even nation-wide)

Figure 4(A): Map West-North Melbourne Infected zones centred on "Reservoir".

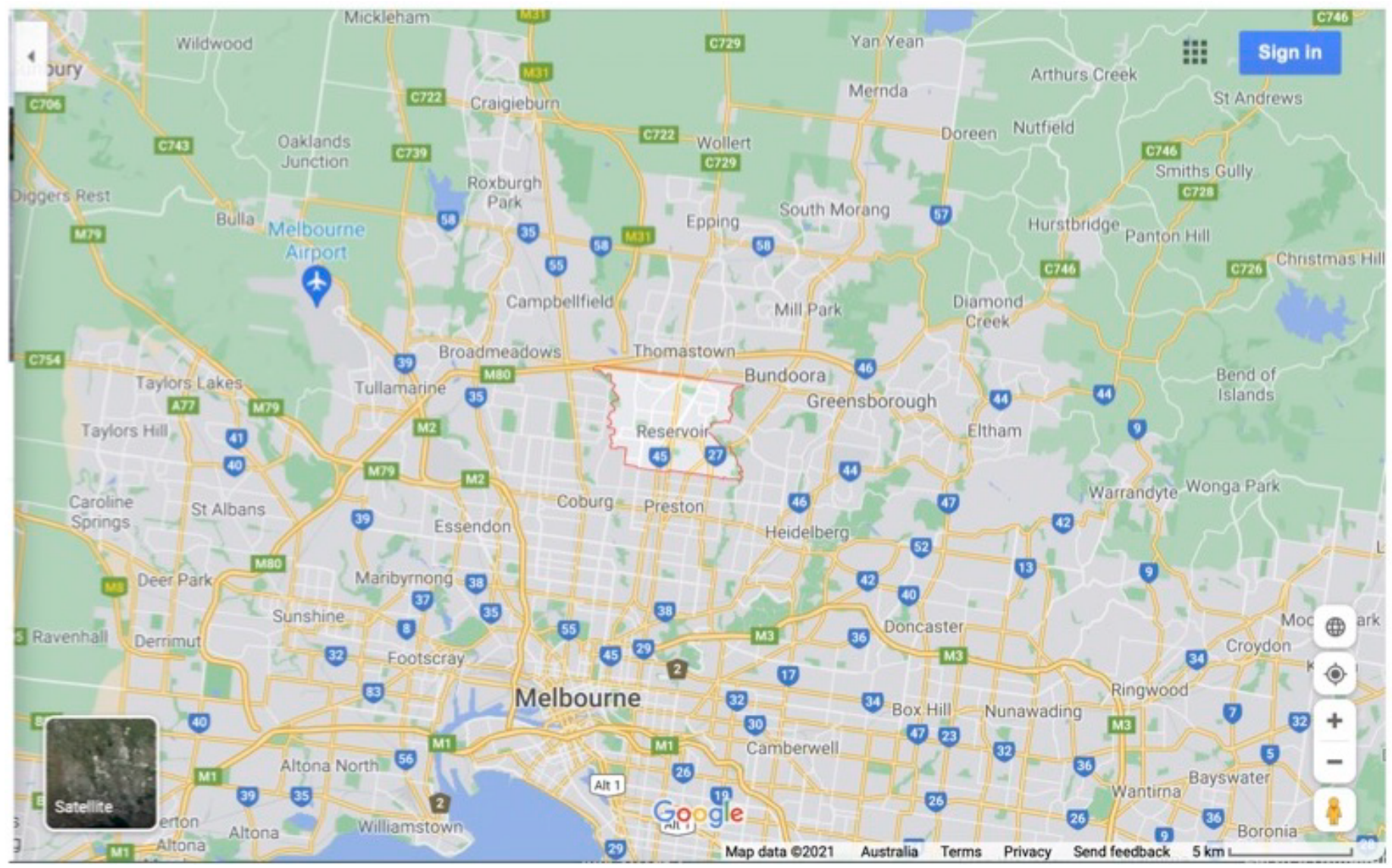


Figure 4(B): Map West-North Melbourne Infected zones centred on "North Melbourne Primary School".

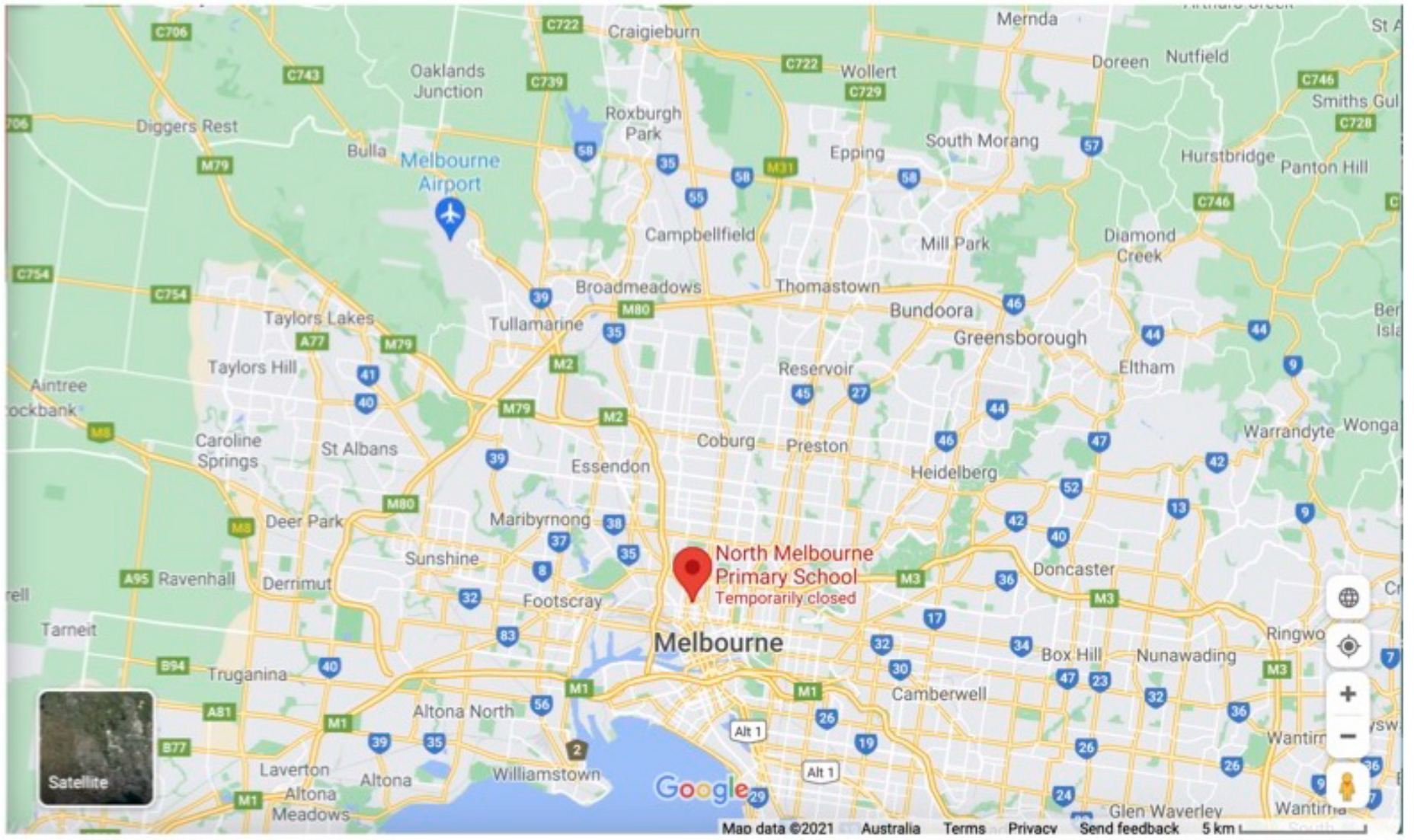

searches for the 'missing links' between clusters. They have not been found. To claim, as indicated in Materials \& Methods, that Wollert Man or those in the larger Whittlesea LGA cluster are of the kappa Indian variant does not constitute evidence of a direct genomic link-in a situation as in Wollert $\mathrm{v}$ Whittlesea where no direct physical P-to-P links can be established. The article by The Australian's Stephen Lunn on the origins of 'Wollert Man' catching a kappa variant by a putative fleeting 18 second contact in a corridor at the Playford quarantine hotel in Adelaide CBD cannot be taken seriously in the light of all the other epidemiological evidence (discussed below)

\section{- Wollert Man (Indian Variant Kappa B.1.617.1)}

Wollert Man, a 30 yr male returned home to Australia on April 20 from India via Adelaide airport and went into hotel quarantine. Over the next 2 weeks he had 3 negative PCR tests. On May 4 he travelled to Adelaide airport, caught a plane to Melbourne, travelled from the airport by Sky bus to Melbourne's Southern Cross Station in the CBD, then caught the train north to Wollert, where he lived. According to reports he had some symptoms on May 8 and was PCR positive on May 11. His close contacts in the household have not become PCR positive. He had limited movement while in Wollert (in the Whittlesea LGA) but all subsequent tests on all those putatively contacted by him on his May 4 travel to Wollert and since (several hundred contacts) have scored PCR negative. In addition there was no transmission of the Playford hotel kappa Indian variant in Adelaide or anywhere in South Australia. The later kappa Indian cluster in Whittlesea LGA (on
May 24) some 5 to $10 \mathrm{~km}$ from his Wollert home has no direct link to Wollert man- only the loose 'kappa variant' associations highlighted by the media and the Victorian Department of Health discussed already and in Materials and Methods (and Supplementary Information).

The most parsimonious interpretation of these data is that Wollert Man became infected when he returned to the already COVID-19 contaminated environment in Wollert on his return. He did not overtly transfer the infection after that date. This is a real genuine infall infection from the troposphere with an already human passaged common Indian variant (Table 2).

\section{- Whittlesea Cluster (Indian Variant Kappa B.1.617.1)}

This is a much larger cluster that emerged suddenly on May 24 and grew to about 20 cases in a few days (Figure 2), then to even greater numbers $>60$ cases (Figure 3 and Supplementary Information). We have established there is no link with Wollert Man. We have no idea if there is more than one kappa mystery infection that initiated the P-to-P expansion. It is conceivable there may have been more than one pro-band. The situation remains confused and that point is not resolved. This cluster is not linked genomically or by any P-to-P contact with the other mystery clusters (below).

\section{- Arcare Outbreak (Variant Non-Indian Kappa or Delta)}

This case appeared suddenly on May 302021 in a 55 yr female carer at the Arcare aged care facility in Maidstone, West Melbourne (see Supplementary Information). It was passed to several elderly residents (> 
Edward J. Steele (2021) COVID-19 Sudden Outbreak of Mystery Case Transmissions in Victoria, Australia, May-June 2021: Strong Evidence of Tropospheric Transport of Human Passaged Infective Virions from the Indian Epidemic

$80 \mathrm{yr}$ ) and also to another female carer who was also working in another local aged care facility (Sunshine). Of interest the $55 \mathrm{yr}$ female carer had already had one COVID-19 vaccination, and the resident she passed it to ( $90 \mathrm{yr}$ male) had a full course of two vaccinations. The elderly infected residents were transferred to hospital and seem to have recovered at time of writing. The Arcare facility is in lockdown at time of writing.

\section{- Delta Cluster, Nth Melbourne (Indian Delta B.1.617.2)}

This cluster emerged around June 4. It involved two families from North Melbourne who travelled together on holiday to the South Coast of NSW in the same large people moving van. Most members of that travelling group have become PCR positive. There are no physical or genomic links to any other cluster. But a supposed link with a 'delta' Indian variant brought from overseas by a Sri Lankan traveller to Melbourne has been hypothesized (see Supplementary Information). The most parsimonious explanation is this is a genuine mystery cluster as recognized by authorities. Whether one or several mystery infected probands in that van is responsible for initiating P-to-P spreads is not known.

\section{- Reservoir Cluster (Variant Non-Indian Kappa or Delta)}

This appeared suddenly on June 102021 and "includes a man in his 80 s, a woman in her 70s, a man in his 50s and a man in his 20s who all live in the same household in Reservoir in Melbourne's northern suburbs" (see Supplementary Information). There is no genomic or physical P-to-P link with any other cluster. It is clear the coronavirus variants driving the mystery clusters in the Victoria outbreak are diverse and typical of prior P-to-P passaged virus variants (Table 2). Where did they suddenly and mysteriously come from? This, we would argue, is a classic signature of spot "infections from the sky" over a regional arc known to have been previously contaminated with COVID-19 genomes on a regional scale. So all these cases are fully consistent with an aerial pathogenic attack from the troposphere, contaminating the environment and capriciously infecting unsuspecting victims as we have discussed in other recent papers.

\section{Possible Explanations}

Ab Initio haplotype sorting of meteorite dust raw virus seems highly unlikely given the clear evidence of complex human-passaged variants, many of which appear to have come from the Indian subcontinent epidemic (Table 2). The variant diversity in India is remarkably wide, and not confined to the main "Indian variants" kappa and delta. It includes even the 'UK Mutant' (B.1.1.7) which has become engaged in the Indian epidemic (Figures 1, 3 and Table 2). Indeed, in a sample of recent Indian PANGO variants that were uploaded to NCBI Virus we find at least 5 that are of concern in Victoria (Figure 3 and Table 2) have also been found in India. Thus PANGO variants and numbers uploaded in this small sample, as determined over the first two hundred upload web pages - each page can accommodate 200 entries- on June 6 and 7 (in brackets) are : B.1.1.7 (11), B.1.617.1 (4), B.1.617.2 (33), B.1.36.8(10), B.1.36 (14), B.36.10 (1), B.1 (2), B.1.1.216 (3), B.1.367 (2), B.1.1 (4), B.1.1.306 (1), B.1.36.17 (1), B.1.351, (5), B.1.427/B.1.429 (2) (see Supplementary Information). So just how did these mature human-passaged Indian variants appear mysteriously in Victoria from a tropospheric in-fall?
The recent outbreak in India is massive and cataclysmic. It has engaged almost all Indian provinces suddenly across the entire subcontinent (not shown, use URL in Figure 1 to check this fact out). We have speculated in the past that it has been triggered on scale by a viral laden dust comet dust in-fall off the $40^{\circ} \mathrm{N}$ Latitude band on the southern side of the Himalayan Mountains [3]. However, we can plausibly include, at a slightly later time, the Sri Lankan and Maldives outbreaks as also coming from India (Supplementary Information). Indeed, as we continue to marshal the relevant evidence, there is in fact a temporal sequential order of outbreaks further south on that same longitude line down the East African coast. New COVID-19 outbreaks of variable magnitude, temporally following India, appear evident in Kenya, Madagascar and South Africa. It is thus conceivable that the putative virus-laden plume (heterogeneous collection of human passaged COVID-19 viral variants) over India has been transported by tropospheric Indian Ocean and Southern Ocean prevailing winds to also cause the comparatively minor outbreak in Victoria, Australia in May-June 2021.

The prevailing winds in the Indian and Southern Ocean (Figure 5) make this global tropospheric transport route entirely credible. And indeed, the recent "upticks" in the rolling waves of Chilean epidemics suggest that the entire Roaring Forties $40^{\circ} \mathrm{S}$ line may now be entrapped by the tropospheric viral clouds from the plume of the Indian epidemic (Supplementary Information). Other independent evidence supporting this interpretation has been documented in the past for the global transport and spread of previous Influenza pandemics by global weather and wind systems $[10,19]$. Further, in the case COVID-19 in the first few months of the pandemic, the Wuhan plume carrying the dominant human passaged haplotype (L) appeared to have crossed the North Pacific by mid-February 2020 to infect passengers on the Grand Princess cruise ship who displayed genomic sequences of unmutated or lightly mutated L haplotype as discussed $[3,18]$.

\section{Conclusions}

It is plausible in the light of this analysis of a defined small COVID-19 outbreak that other global transfers of viral plumes are conceivable. The "UK Mutant" B.1.1.7 is now widespread and very common in the USA (inspection of the very large numbers of uploads of B.1.1.7 variants to NCBI Virus confirms this impression) and including many parts of Europe. These global transportations again via lower-level E-to-W and W-to-E tropospheric winds seem plausible given the expected size of the viral plume over the UK epidemic Dec-Feb (Figure 1). There are many unknowns on the size and potential rising-height of the putative viral plumes, so plausible speculation is required. From available epidemiological data (e.g. Figure 1) which suggest an estimated 10 million active Indian cases at any given time over several weeks ( 20 days of say 500,000 cases per day), we would have $\sim 10^{7}$ virus exhalers who undoubtedly contribute virions into the lower atmosphere. If we assume that each infected "exhaler" conservatively contributes $10^{12}$ aerosol virions we would have a total of $10^{19}$ virions potentially arising from the surface of the Indian subcontinent. Such virions which pass through regions of high humidity would be expected to acquire outer mantles of water ice that could help to retain viability to some degree. Fukuta et al. have recently 
Figure 5: Prevailing winds in Indian and Southern Oceans

Google link to Indian Ocean winds at: https://www.google.com.au/search?source=univ\&tbm=isch\&q=indian+ocean+prevailing+winds\&hl=en\&sa=X\&ved=2ahUKEwiKpNCLqoTxAhUmzT gGHQEfBHkQjJkEegQIChAB\&biw=1018\&bih=602\&dpr=2

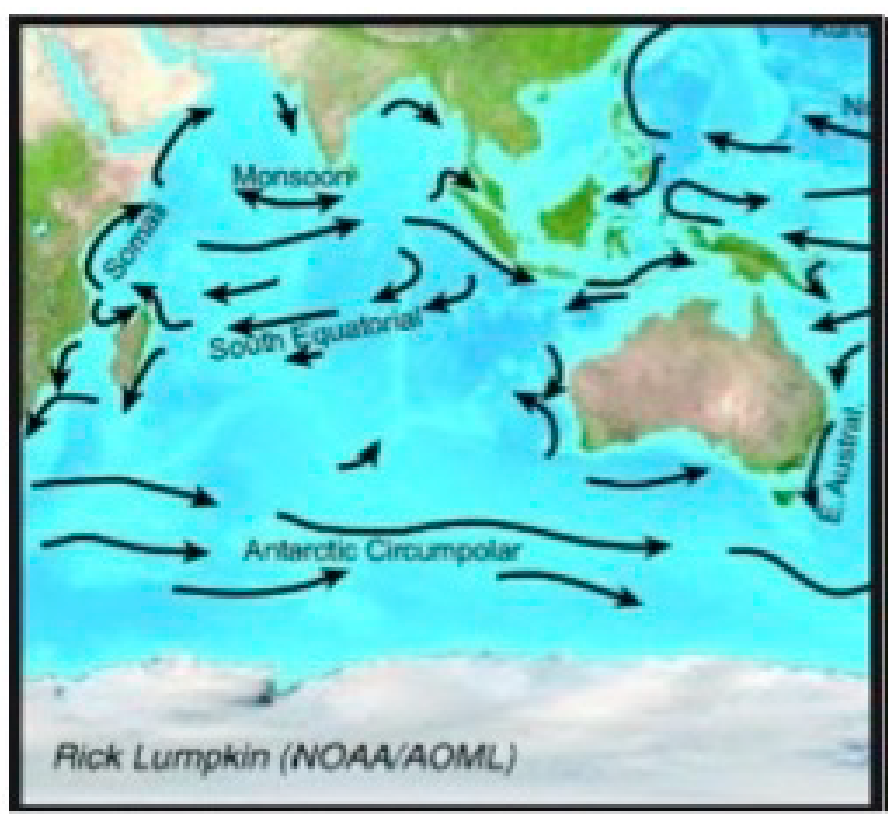

Indian Ocean- a Cruising Guide cruiserswiki.org

shown that COVID-19 remains highly infectious for prolonged periods in cold and wet conditions [24]. In addition, Kwon et al. [25] have determined the stability of the virus in a variety of biological fluids (nasal mucus, sputum, saliva, tear, urine, blood, and semen) and "it remained infectious significantly longer under winter and spring/fall conditions than under summer conditions". This suggests that dispersed viruses in aerosol biological fluid protective wraps may add to putative stability. If say $10 \%$ of these aerosol-protected virions survive lofting into the troposphere and subsequent wind transport, we have some $10^{18}$ virions (all amplified by victims in India) that are in circulation and which could contribute to the outbreaks of the socalled mystery clusters in Victoria, Australia. Indeed as this paper was being submitted it seems that the southern Chinese city of Guangzhou may be engaged in a sudden tropospheric strike of variants from India. Further, many other Northern Hemisphere countries (Russia, UK, USA) are also reporting the sudden spread of the Indian delta variant on real population wide scale (for news links see Supplementary Information File)

Given these developments, and on reflection, the sudden large outbreak in Sri Lanka October 4 - 62020 may well have been due to the 1st Wave Indian human-passaged viral plume (see Figure 1 and Supplementary Information). In contradistinction, the recent In Press report of Althoff et al. [26] of early spot detections and spreads of COVID-19 (late 2019-early 2020) suggest early fragmented in-fall of small clouds of raw (non P-to-P passaged) meteorite dust COVID-19 from the stratosphere on the $40^{\circ} \mathrm{N}$ latitude line as discussed viz [14]. " 7 individuals had detectable SARS-CoV-2 immunoglobulin G prior to the first confirmed case in the states of Illinois, Massachusetts, Wisconsin, Pennsylvania, and Mississippi, suggesting that SARS-CoV-2 infections were occurring weeks prior to recognized cases in at least 5 US states [26]."

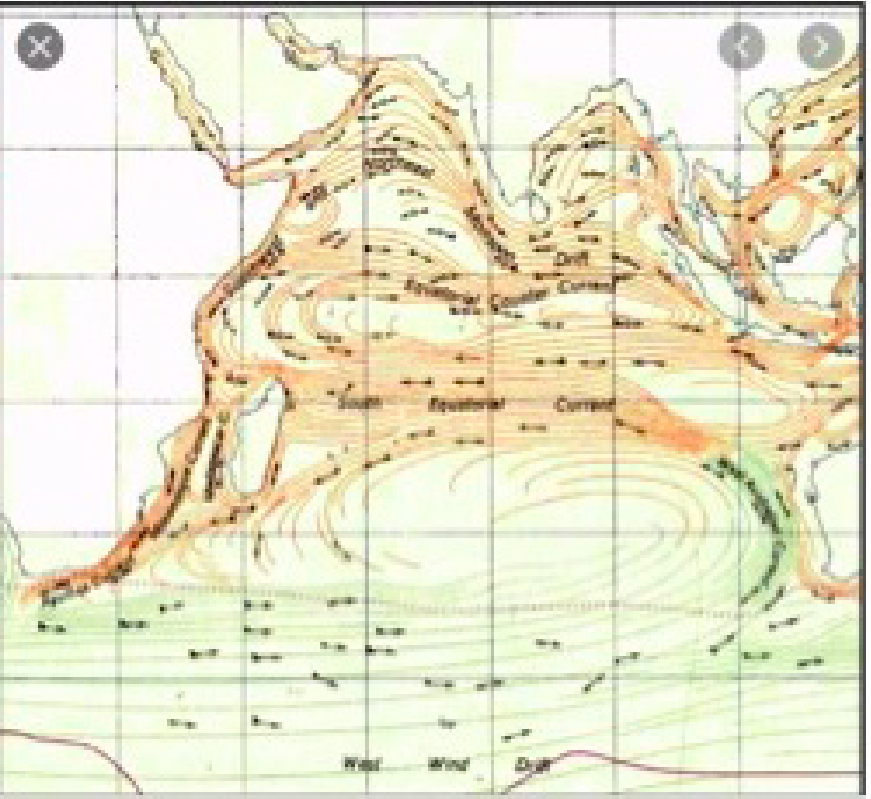

\section{Indian Ocean Gyre - Wikipedia}

What lessons can we learn? Certainly, near-Earth surveillance of incoming pathogens from space, such as the suggested "Hoyle" shield needs to be an international imperative [27], as often reiterated by us $[3,28]$, including for monitoring for tropospheric global transport of viral plumes as discussed here. But it seems also that once a viral pandemic is already underway, rising viral-plumes from major infected zones can potentially be transported to infect other global regions on a mass scale. Indeed pathogenic re-circulation via the troposphere during a pandemic is a major factor to consider for societies whose thinking seems restricted to "hard lockdowns and social distancing" to prevent or alleviate the spread of airborne viruses. If it is considered feasible a procedure by which the lower atmosphere and environments of infected areas could be sprayed with suitable disinfectants from the air must surely deserve serious attention. Face masks may be useful during an actual tropospheric in-fall event but may not work in the way the health authorities have advocated during a real mass outbreak on the scale of trillions of infectious virions falling from the sky. All the evidence from the $2^{\text {nd }}$ Wave in the Victorian 2020 epidemic suggests the Stage 4 lockdown had no impact whatsoever on the course of the epidemic [3], a conclusion supported by critical analysis of similar lock downs in the USA [29].

What of the immediate future? Has all the raw cometary dustprotected virus or the P-to-P plumed-virus (almost certainly assisted and protected by pollution particles) [30,31], washed down from the troposphere? The Spanish Flu took two years to run its full course. COVID-19 is nowhere as lethal but its global reach is similar, implying a similar magnitude of initiating viral inoculation. If that is a valid comparison then full viral wash down could perhaps take another 6 months. This time frame is not incompatible with other micronsized particle falling-rates as estimated for wash down of radioactive 
Edward J. Steele (2021) COVID-19 Sudden Outbreak of Mystery Case Transmissions in Victoria, Australia, May-June 2021: Strong Evidence of Tropospheric Transport of Human Passaged Infective Virions from the Indian Epidemic

tracers following upper-atmosphere nuclear tests in the late 1950s [2]. In conclusion we stress that as scientists we have a responsibility to accept whatever facts that the universe presents us without fear or favour. Distorting or even simply tweaking emerging facts in order to fit a long-established paradigm should be avoided at all cost.

\section{Acknowledgement}

We thank Max K. Wallis for critical discussions on the pandemic contributions of rising plumes of P-to-P virus, particularly the Wuhan COVID-19 plume of January 2020. George Howard is thanked for bringing to our attention the recent study by Althoff KN, Schlueter DJ, Anton-Culver H, Cherry J, Denny JC, et al. (2020). We thank John A Schuster for a critical reading of the manuscript first draft.

\section{References}

1. Wickramasinghe NC, Steele EJ, Gorczynski RM, Temple R, Tokoro G, et al. (2020) Comments on the Origin and Spread of the 2019 Coronavirus. Virology: Current Research 4:1. DOI: 10.37421/Virol Curr Res.2020.4.109

2. Steele EJ, Gorczynski RM, Lindley RA, Tokoro G, Temple R, et al. (2020) Origin of new emergent Coronavirus and Candida fungal diseases- Terrestrial or Cosmic? Advances in Genetics 106: 75-100. [crossref] https://doi.org/10.1016/bs.adgen.2020.04.002

3. Steele EJ, Gorczynski RM, Lindley RA, Tokoro G, Wallis DH, et al. (2021) Cometary Origin COVID-19 Infect Dis \& Therapeutics 2: 1-4. DOI: 10.31038/IDT.2021212

4. Wainwright M, Wickramasinghe NC, Narlikar JV, Rajaratnam P, Perkins Joy (2004). Confirmation of the presence of viable but non-culturable bacteria in the stratosphere. Int. J. Astrobiology 3: 13-15. DOI: https://doi.org/10.1017/S1473550404001739

5. Wainwright M, Wickramasinghe NC, Tokoro G (2021) Neopanspermia - evidence that life continuously arrives at the Earth from space. Advances in Astrophysics. In Press

6. Grebennikova TV, Syroeshkin AV, Shubralova EV, Eliseeva OV, Kostina LV, et al. (2018) The DNA of bacteria of the world ocean and the Earth in cosmic dust at the international space station. Sci. World J. https://doi.org/10.1155/2018/7360147

7. Steele EJ, Al-Mufti S, Augustyn KA, Chandrajith R, Coghlan JP, et al. (2018) Cause of Cambrian Explosion: Terrestrial or Cosmic? Prog. Biophys. Mol. Biol 136: 3-23. [crossref] https://doi.org/10.1016/j.pbiomolbio.2018.03.004

8. Steele EJ, Gorczynski RM, Lindley RA, Liu Y, Temple R, et al. (2019) Lamarck and Panspermia - On the Efficient Spread of Living Systems Throughout the Cosmos. Prog. Biophys. Mol. Biol 149: 10-32. https://doi.org/10.1016/j.pbiomolbio.2019.08.010

9. Steele EJ, Gorczynski RM, Rebhan H, Carnegie P, Temple R, et al. (2020) Implications of haplotype switching for the origin and global spread of COVID-19 Virology: Current Research DOI: 10.37421/Virol Curr Res.2020.4.115

10. Hoyle F, Wickramasinghe NC (1979) Diseases from Space JM Dent Ltd, London.

11. Hoyle, F and Wickramasinghe, NC. (2000) Astronomical Origins of Life: Steps Towards Panspermia. Klower Academic Publishers, Dordrechl, The Netherlands.

12. Steele EJ, Wickramasinghe NC (Editors) (2020) Cosmic Genetic Evolution. Advances in Genetics. 106: 2-143.

13. Wickramasinghe NC, Steele EJ, Gorczynski RM, Temple R, Tokoro G, et al. (2020) Growing Evidence against Global Infection-Driven by Person-to-Person Transfer of COVID-19 Virology: Current Research 4:1. DOI: 10.37421/Virol Curr Res.2020.4.110
14. Wickramasinghe NC, Steele EJ, Gorczynski RM, Temple R, Tokoro G, et al. (2020) Predicting the Future Trajectory of COVID-19. Virology: Current Research 4:1. DOI: 10.37421/Virol Curr Res.2020.4.111

15. Wickramasinghe NC, Wallis MK, Coulson SG, Kondakov A, Steele EJ, et al.(2020) Intercontinental Spread of COVID-19 on Global Wind Systems Virology: Current Research 4:1.DOI: 10.37421/Virol Curr Res.2020.4.113

16. Howard GA, Wickramasinghe NC, Rebhan H, Steele EJ, Gorczynski RM, et al. (2020) Mid-Ocean Outbreaks of COVID-19 with Tell-Tale Signs of Aerial Incidence Virology: Current Research 4:2. DOI: 10.37421/Virol Curr Res.2020.4.114

17. Wickramasinghe NC, Steele EJ, Nimalasuriya A, Gorczynki RM, Tokoro G, et al (2020) Seasonality of Respiratory Viruses Including SARS-CoV-2 Virology: Current Research 4:2. DOI: 10.37421/VCRH.2020.4.117

18. Steele EJ, Lindley RA (2020) Analysis of APOBEC and ADAR deaminase-driven Riboswitch Haplotypes in COVID-19 RNA strain variants and the implications for vaccine design. Research Reports. https://companyofscientists.com/index.php/rr

19. Hammond GW, Raddatz RL, Gelskey DE (1989) Impact of atmospheric dispersion and transport of viral aerosols on the epidemiology of Influenza. Reviews of Infectious Disease 11: 494- 497. [crossref] https://doi.org/10.1093/clinids/11.3.494

20. Rambaut A, Holmes EC, O’Toole Á, Hill V, McCrone JT, et al. (2020) A dynamic nomenclature proposal for SARS- CoV-2 to assist genomic epidemiology. Nat. Microbiol 5: 1403-1407. [crossref] https://doi.org/10.1038/s41564-020-0770-5

21. Forster P, Forster L, Renfrew C, Forster M (2020) Phylogenetic network analysis of SARS-CoV-2 genomes. Proc. Natl. Acad. Sci USA 117: 9241-9243. https://doi org/10.1073/pnas.2004999117

22. Eigen M, Schuster P (1979) The Hypercycle: A Principle of Natural Self-Organization. Springer, Berlin.

23. Andino R, Domingo E (2015) Viral quasispecies. Virology 479-480: 46-51. [crossref] https://doi.org/10.1016/j.virol.2015.03.022

24. Fukuta M, Mao ZQ, Morita K, Moi ML (2021) Stability and Infectivity of SARS CoV-2 and viral RNA in Water, Commercial Beverages, and Bodily Fluids. Front. Microbiol 12: 667956. [crossref] https://doi.org/10.3389/fmicb.2021.667956

25. KwonT, Gaudreault NN, Richt JA (2021) Seasonal Stability of SARS-CoV-2 in Biological Fluids. Pathogens 10: 540. https://doi.org/10.3390/pathogens10050540

26. Althoff KN, Schlueter DJ, Anton-Culver H, Cherry J, Denny JC, et al. (2020) Antibodies to SARS-CoV-2 in All of Us Research Program Participants, January 2-March 18, 2020. Clinical Infectious Diseases. https://academic.oup.com/cid/ advance-article/doi/10.1093/cid/ciab519/6294073

27. Smith WE (2013) 2013; Life is a cosmic phenomenon: the Search for Water evolves into the Search for Life. Hoover RB, Levin GV, Rozanov AY, Wickramasinghe NC (Eds.). Proc. SPIE 8865, Instruments, Methods, and Missions for Astrobiology XVI. San Diego, California, United States. https://doi.org/10.1117/12.2046862.

28. Qu J, Wickramasinghe NC (2020) The world should establish an early warning system for new viral infectious diseases by space-weather monitoring. MedComm 1: 423-426. DOI: $10.1002 / \mathrm{mco} 2.20$

29. Luskin DL (2020) The failed experiment of COVID-19 lockdowns. The Wall Street Journal. Sept 2.

30. Coccia M (2020) Factors determining the diffusion of COVID-19 and suggested strategy to prevent future accelerated viral infectivity similar to COVID. Science of the Total Environment 729: 138474. https://doi.org/10.1016/j.scitotenv.2020.138474

31. Martelletti L, Martelletti P (2020) Air Pollution and the Novel Covid-19 Disease: a Putative Disease Risk Factor. SN Compr. Clin. Med 2: 383-387. https://doi. org/10.1007/s42399-020-00274-4

\section{Citation:}

Steele EJ, Gorczynski RM, Carnegie P, Tokoro G, Wallis DH, et al. (2021) COVID-19 Sudden Outbreak of Mystery Case Transmissions in Victoria, Australia, May-June 2021: Strong Evidence of Tropospheric Transport of Human Passaged Infective Virions from the Indian Epidemic. Infect Dis Ther Volume 2(1): 1-28. 


\section{Supplementary Information}

COVID-19 sudden outbreak of mystery case transmissions in Victoria Australia, MayJune 2021 : Strong evidence of tropospheric transport of human passaged infective virions from the Indian epidemic

Edward J. Steele, Reginald M. Gorczynski, Patrick Carnegie, Gensuke Tokoro, Daryl H. Wallis, Robert Temple, Milton Wainwright and N. Chandra Wickramasinghe

We address here issues as Supplementary Information to assist understanding of the main text. For some computer systems the entire URL link may need to be copied and pasted into Search bar to obtain link.

A. Fragility of paradigms- Ptolemaic epicycles just prior to the first Copernican revolution from the $16^{\text {th }}$ Century

B. COVID-19 Cases per Day in Australia (Victoria), India, Sri Lanka, Maldives, Kenya, Madagascar, South Africa, Chile

C. Distribution of Cases and Clusters in Greater Melbourne Victoria from May - June 2021

D. Recent Indian PANGO variants NCBI Virus Page 2/ 2855 pages- Screen Shots as 6 June 2021

E. Newspaper and Media Reports - all significant relevant coverage

F. Indian 'delta' variant (B.1.617.2) now going global as June 192021

A.Figure shows Ptolemaic epicycles just prior to the first Copernican revolution from the $16^{\text {th }}$ Century

See also Wickramasinghe, Steele, Gorczynski et al (2020) Virology Current Research

On the Fragility of Empires and Paradigms Virology Current Research Volume 4:1,2020

DOI: 10.37421 /Virol Curr Res.2020.4.112

https://www.hilarispublisher.com/open-access/on-the-fragility-of-empires-and-paradigms.pdf



B.COVID-19 Cases per Day in Australia (Victoria), India, Sri Lanka, Maldives, Kenya, Madagascar,

South Africa, Chile Google: "Coronavirus disease statistics"URL is

https://www.google.com.au/search?hl=en\&ei=vWxyX7ipM4-

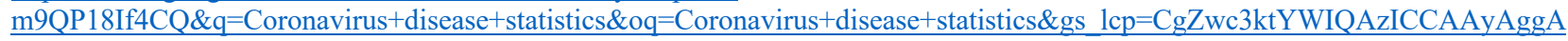

OgQIABBHOgcIABCxAxBDOgQIABBDULZUWPh1YJF7aABwAXgAgAH2AYgBvA6SAQYwLjEwLjGYAQCgAQGqAQdnd3

Mtd216yAEGwAEB\&sclient=psy-ab\&ved=0ahUKEwj4-47e-4zsAhUPU30KHXX4AZ8Q4dUDCAw\&uact=5

This gives you the "Australia" Victoria dashboard (from there you can choose your country in the menu bar scroll) 
Edward J. Steele (2021) COVID-19 Sudden Outbreak of Mystery Case Transmissions in Victoria, Australia, May-June 2021: Strong Evidence of Tropospheric Transport of Human Passaged Infective Virions from the Indian Epidemic

\section{Statistics}

New cases and deaths

From JHU CSSE COVID-19 Data · Last updated: 2 days ago

New cases - Australia - Victoria - All time -

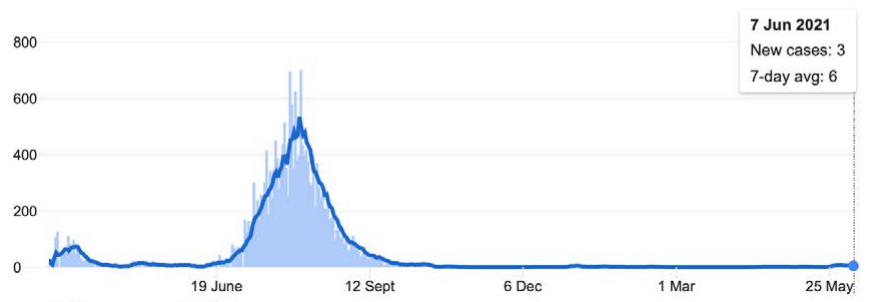

\section{Statistics}

New cases and deaths

From JHU CSSE COVID-19 Data · Last updated: 2 days ago
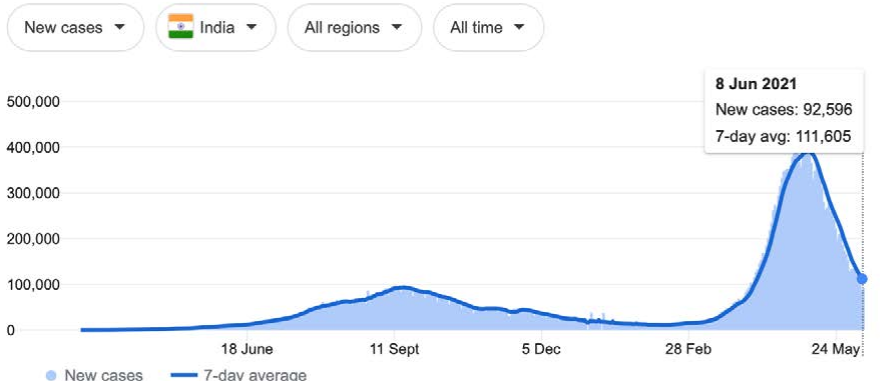

\section{Statistics}

\section{New cases and deaths}

From JHU CSSE COVID-19 Data · Last updated: 2 days ago

New cases - IE Sri Lanka - All time -

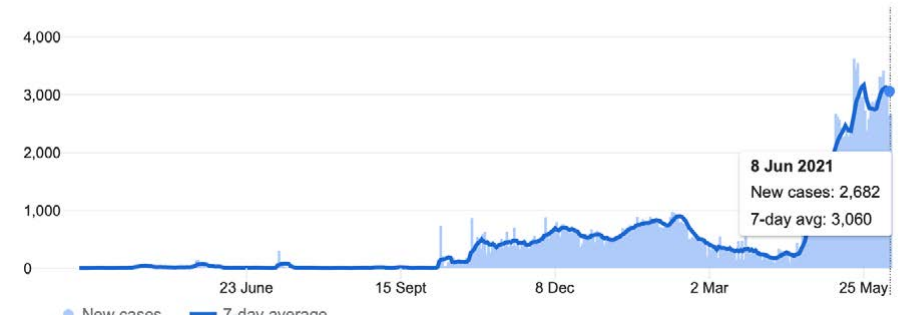

\section{Statistics}

\section{New cases and deaths}

From JHU CSSE COVID-19 Data · Last updated: 2 days ago

New cases $-\quad$ Maldives - All time -

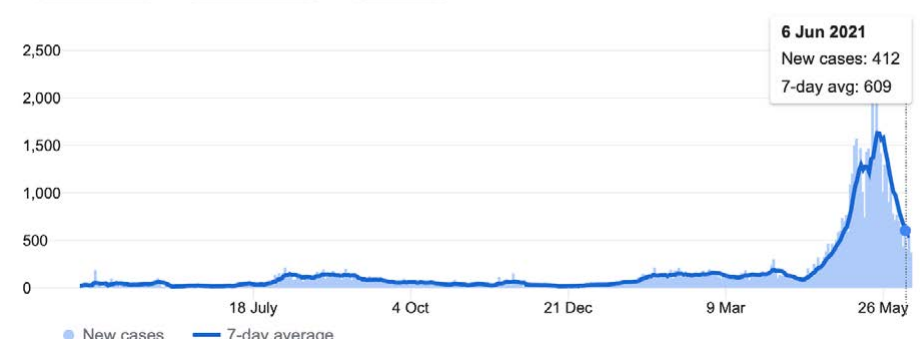


Edward J. Steele (2021) COVID-19 Sudden Outbreak of Mystery Case Transmissions in Victoria, Australia, May-June 2021: Strong Evidence of Tropospheric Transport of Human Passaged Infective Virions from the Indian Epidemic

\section{Statistics}

New cases and deaths

From JHU CSSE COVID-19 Data · Last updated: 2 days ago

New cases $-\quad$ 필 Kenya $>$ All time -

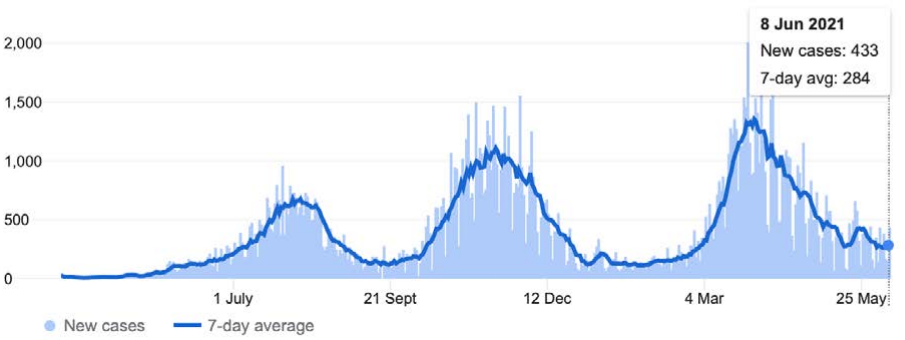

\section{Statistics}

\section{New cases and deaths}

From JHU CSSE COVID-19 Data · Last updated: 2 days ago

New cases - Madagascar - All time -

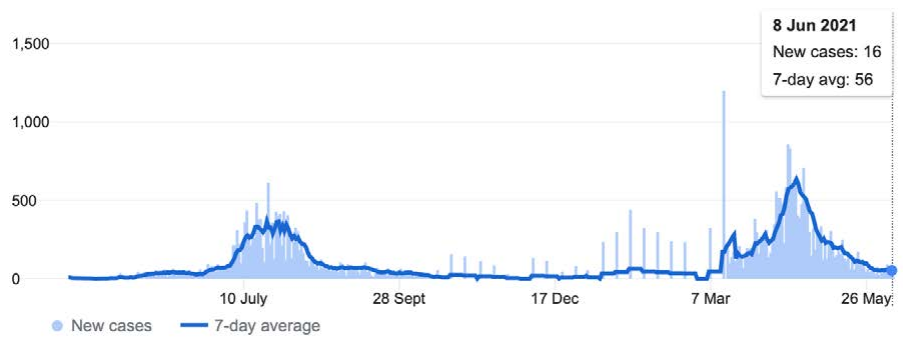

New cases $\quad$ - 7-day average

Each day shows new cases reported since the previous day - About this data

\section{Statistics}

\section{New cases and deaths}

From JHU CSSE COVID-19 Data · Last updated: 2 days ago

New cases - $\$$ South Africa - All time -

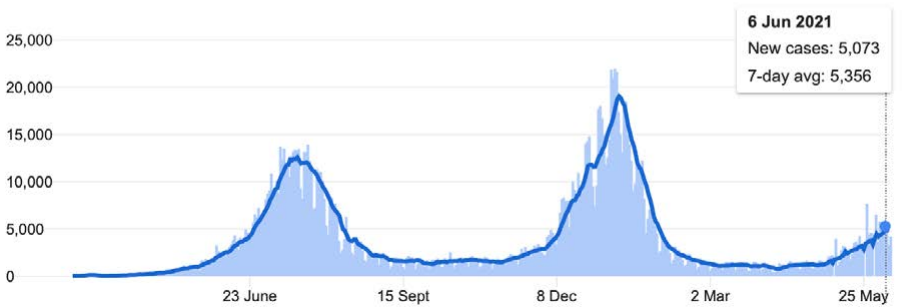

\section{Statistics}

\section{New cases and deaths}

From Wikipedia · Last updated: 9 hours ago

New cases - All regions - All time -

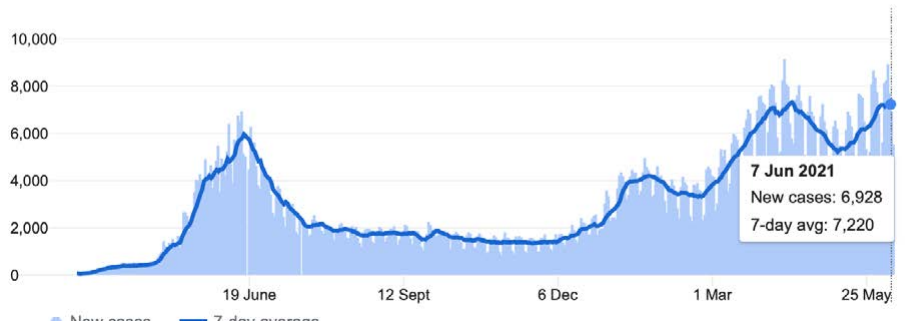

- New cases $\quad$ 7-day average 


\section{Distribution of Cases and Clusters in Greater Melbourne Victoria from May - June 2021}

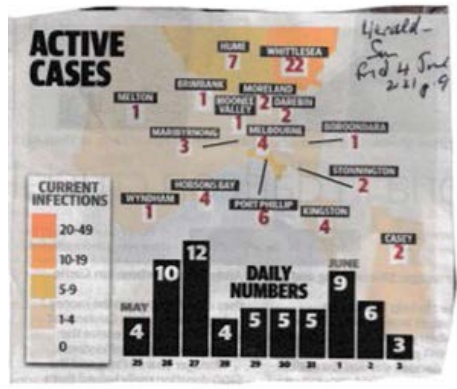

Source : The Herald-Sun 4 June 2021

\section{Recent Indian PANGO variants NCBI Virus Page 2/ 2855 pages- Screen Shots as 6 June 2021}

\begin{tabular}{|c|c|c|c|c|c|c|c|c|}
\hline$\square$ & Accession $\triangleq$ & Submitters $=$ & Release Date ₹ & Pangolin $=$ & Species $\approx$ & Molecule type $=$ & Length $=$ & Geo Location $\triangleq$ \\
\hline$\square$ & MZ317887 & Lemieux,J.... & 2021-06-01 & B.1.1.7 & Severe acute respiratory s... & $\operatorname{ssRNA}(+)$ & 29680 & USA: Rhode Islar \\
\hline$\square$ & MZ317890 & Sharma,S., ,... & 2021-06-01 & B.1.351 & Severe acute respiratory s... & ssRNA $(+)$ & 29784 & India \\
\hline$\square$ & $\underline{M Z 317891}$ & Saiyed,z., e... & 2021-06-01 & B.1.351 & Severe acute respiratory s... & $\operatorname{ssRNA}(+)$ & 29784 & India \\
\hline$\square$ & MZ317892 & Raval,J., et al. & 2021-06-01 & B.1.351 & Severe acute respiratory s... & $\operatorname{ssRNA}(+)$ & 29784 & India \\
\hline$\square$ & MZ317893 & Pandit,R., e... & 2021-06-01 & B.1.351 & Severe acute respiratory s... & ssRNA $(+)$ & 29784 & India \\
\hline$\square$ & MZ317894 & Savaliya,N.,... & 2021-06-01 & B.1.36 & Severe acute respiratory s... & ssRNA $(+)$ & 29802 & India \\
\hline$\Pi$ & MA721700K & Mitamam M & onmenani, & D 1197 & 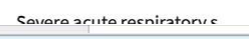 & CEDNAN/AI & 20702 & Carmanin Eranltt \\
\hline$\square$ & Accession $\Rightarrow$ & Submitters $\triangleq$ & Release Date $\triangleq$ & Pangolin ₹ & Species $\hat{=}$ & Molecule type $\Rightarrow$ & Length $\triangleq$ & Geo Location $\triangleq$ \\
\hline$\square$ & MZ317896 & Widera,M., ... & 2021-06-01 & B.1.429 & Severe acute respiratory s... & ssRNA(+) & 29782 & Germany: Frankf \\
\hline$\square$ & MZ317905 & Saiyed,z., e... & 2021-06-01 & B.1.1.7 & Severe acute respiratory s... & $\operatorname{ssRNA}(+)$ & 29783 & India \\
\hline$\square$ & MZ317906 & Soni,T., et al. & 2021-06-01 & B.1.36.10 & Severe acute respiratory s... & ssRNA(+) & 29802 & India \\
\hline$\square$ & $\underline{\text { MZ317907 }}$ & Sharma,S., ... & 2021-06-01 & B.1 & Severe acute respiratory s... & ssRNA(+) & 29802 & India \\
\hline$\square$ & MZ317908 & Kumar,D., e... & 2021-06-01 & B.1.351 & Severe acute respiratory s... & ssRNA(+) & 29784 & India \\
\hline$\square$ & MZ317915 & Pandit,R., e... & 2021-06-01 & B.1.1.7 & Severe acute respiratory s... & $\operatorname{ssRNA}(+)$ & 29783 & India \\
\hline$\square$ & MZ317916 & Raval,J., et al. & 2021-06-01 & B.1.1.7 & Severe acute respiratory s... & ssRNA(+) & 29783 & India \\
\hline$\square$ & $\underline{\text { MZ317917 }}$ & Kumar,D., e... & 2021-06-01 & B.1.36 & Severe acute respiratory s... & $\operatorname{ssRNA}(+)$ & 29793 & India \\
\hline$\square$ & MZ317918 & Savaliya,N.,... & 2021-06-01 & B.1.1.7 & Severe acute respiratory s... & $\operatorname{ssRNA}(+)$ & 29783 & India \\
\hline$\square$ & $\underline{\text { MZ317919 }}$ & Patel,Z., et al. & 2021-06-01 & B.1.1.7 & Severe acute respiratory s... & $\operatorname{ssRNA}(+)$ & 29783 & India \\
\hline - & & & & - & & & & Gram \\
\hline$\square$ & Accession $\triangleq$ & Submitters $\triangleq$ & Release Date ै & Pangolin $\triangleq$ & Species & Molecule type $\widehat{-}$ & Length $\approx$ & Geo Location $\triangleq$ \\
\hline$\square$ & $\underline{\text { MZ317919 }}$ & Patel,Z., et al. & $2021-06-01$ & B.1.1.7 & Severe acute respiratory s... & $\operatorname{ssRNA}(+)$ & 29783 & India \\
\hline$\square$ & MZ317920 & Saiyed,z., e... & 2021-06-01 & B.1.1.7 & Severe acute respiratory s... & ssRNA(+) & 29783 & India \\
\hline$\square$ & MZ317921 & Sharma,S., ,... & 2021-06-01 & B.1.1.7 & Severe acute respiratory s... & $\operatorname{ssRNA}(+)$ & 29783 & India \\
\hline$\square$ & MZ317922 & Soni,T., et al. & 2021-06-01 & B.1.36 & Severe acute respiratory s... & ssRNA $(+)$ & 29793 & India \\
\hline$\square$ & MZ318037 & Pandit,R., e... & 2021-06-01 & B.1.1.7 & Severe acute respiratory s... & ssRNA $(+)$ & 29783 & India \\
\hline$\square$ & MZ318038 & Kumar,D., e... & 2021-06-01 & B.1.1.7 & Severe acute respiratory s... & ssRNA(+) & 29783 & India \\
\hline$\square$ & MZ318159 & Kanani,A., ... & 2021-06-01 & B.1.617.2 & Severe acute respiratory s... & $\operatorname{ssRNA}(+)$ & 29796 & India \\
\hline$\square$ & MZ318160 & Saiyed,Z., e... & $2021-06-01$ & B.1.617.2 & Severe acute respiratory s... & ssRNA(+) & 29775 & India \\
\hline$\square$ & MZ318161 & Kanani,A., ... & 2021-06-01 & B.1.617.2 & Severe acute respiratory s... & $\operatorname{ssRNA}(+)$ & 29796 & India \\
\hline$\square$ & MZ318201 & Patel,Z., et al. & 2021-06-01 & B.1.617.2 & Severe acute respiratory s... & ssRNA(+) & 29792 & Ine \\
\hline
\end{tabular}


Edward J. Steele (2021) COVID-19 Sudden Outbreak of Mystery Case Transmissions in Victoria, Australia, May-June 2021: Strong Evidence of Tropospheric Transport of Human Passaged Infective Virions from the Indian Epidemic

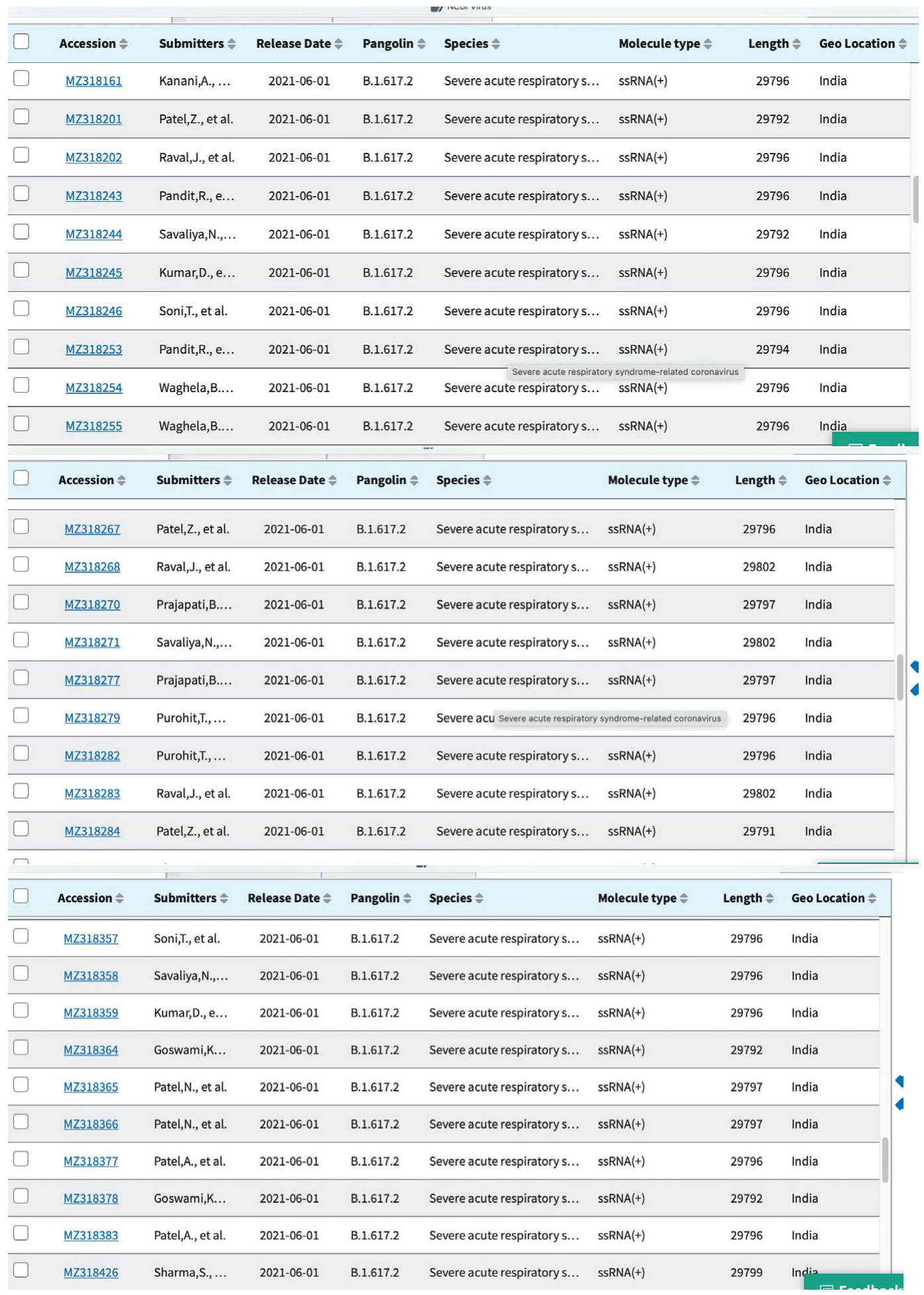


Edward J. Steele (2021) COVID-19 Sudden Outbreak of Mystery Case Transmissions in Victoria, Australia, May-June 2021: Strong Evidence of Tropospheric Transport of Human Passaged Infective Virions from the Indian Epidemic

PANGO variants in India screen shots NCBI Virus page.2010f 2855 pages as 7 June 2021

p. $201 / 2855$

\begin{tabular}{|c|c|c|c|c|c|c|c|c|}
\hline$\square$ & Accession $=$ & Submitters $\Rightarrow$ & Release Date $₹$ & Pangolin : & Species $\Rightarrow$ & Molecule type & Length $\triangleq$ & Geo Location \\
\hline$\square$ & MZ310507 & Sharma,S., et al. & $2021-05-28$ & B.1 & Severe acute respiratory s... & $\operatorname{ssRNA}(+)$ & 29802 & India \\
\hline$\square$ & MZ310508 & Saiyed,Z., et al. & $2021-05-28$ & B.1.1.216 & Severe acute respiratory s... & $\operatorname{ssRNA}(+)$ & 29802 & India \\
\hline$\square$ & MZ310509 & Raval,J., et al. & $2021-05-28$ & B.1.36 & Severe acute respiratory s... & $\operatorname{ssRNA}(+)$ & 29802 & India \\
\hline$\square$ & MZ310510 & Soni,T., et al. & 2021-05-28 & B.1.36 & Severe acute respiratory s... & $\operatorname{ssRNA}(+)$ & 29799 & India \\
\hline$\square$ & MZ310511 & Sharma,S., et al. & 2021-05-28 & B.1.36 & Severe acute respiratory s... & $\operatorname{ssRNA}(+)$ & 29799 & India \\
\hline$\square$ & $\underline{\text { MZ310512 }}$ & Saiyed,z., et al. & $2021-05-28$ & B.1.36.8 & Severe acute respiratory s... & $\operatorname{ssRNA}(+)$ & 29802 & India \\
\hline$\square$ & MZ310579 & Pandit,R., et al. & $2021-05-28$ & B.1.36.8 & Severe acute respiratory s... & $\operatorname{ssRNA}(+)$ & 29802 & India \\
\hline$\square$ & MZ310580 & Raval,J., et al. & $2021-05-28$ & B.1.617.1 & Severe acute respiratory s... & $\operatorname{ssRNA}(+)$ & 29801 & India \\
\hline & 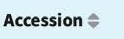 & Submitters $\Rightarrow$ & Release Date $\vee$ & Pangolin $=$ & Species $=$ & Molecule type $=$ & Length $\approx$ & Geo Locatio \\
\hline & MZ310587 & Kumar,D., et al. & $2021-05-28$ & B.1.617.1 & Severe acute respiratory s... & ssRNA $(+)$ & 29801 & India \\
\hline & $\underline{\text { MZ310588 }}$ & Savaliya,N., et al. & $2021-05-28$ & B.1.617.1 & Severe acute respiratory s... & $\operatorname{ssRNA}(+)$ & 29801 & India \\
\hline & $\underline{\text { MZ310589 }}$ & Patel,Z., et al. & $2021-05-28$ & B.1.367 & Severe acute respiratory s... & $\operatorname{ssRNA}(+)$ & 29801 & India \\
\hline J & MZ310590 & Soni,T., et al. & $2021-05-28$ & B.1.617.1 & Severe acute respiratory s... & ssRNA(+) & 29801 & India \\
\hline & MZ310591 & Sharma,S., et al. & 2021-05-28 & B.1.367 & Severe acute respiratory s... & $\operatorname{ssRNA}(+)$ & 29801 & India \\
\hline
\end{tabular}

\begin{tabular}{|c|c|c|c|c|c|c|c|}
\hline MZ292126 & Sharma,S., et al. & $2021-05-26$ & B.1.36 & Severe acute respiratory s... & $\operatorname{ssRNA}(+)$ & 29801 & India \\
\hline MZ292127 & Soni,T., et al. & $2021-05-26$ & B.1.36 & Severe acute respiratory s... & $\operatorname{ssRNA}(+)$ & 29801 & India \\
\hline MZ292128 & Pandit,R., et al. & $2021-05-26$ & B.1.36.8 & Severe acute respiratory s... & ssRNA(+) & 29801 & India \\
\hline MZ292129 & Raval,J., et al. & 2021-05-26 & B.1.36.8 & Severe acute respiratory s... & $\operatorname{ssRNA}(+)$ & 29801 & India \\
\hline MZ292130 & Kumar,D., et al. & $2021-05-26$ & B.1.1.216 & Severe acute respiratory s... & ssRNA(+) & 29801 & India \\
\hline MZ292131 & Soni,T., et al. & $2021-05-26$ & B.1.1.216 & Severe acute respiratory s... & $\operatorname{ssRNA}(+)$ & 29801 & India \\
\hline MZ292132 & Saiyed,Z., et al. & $2021-05-26$ & B.1.36.8 & Severe acute respiratory s... & $\operatorname{ssRNA}(+)$ & 29801 & India \\
\hline MZ292133 & Pandit,R., et al. & $2021-05-26$ & B.1.36.8 & Severe acute respiratory s... & $\operatorname{ssRNA}(+)$ & 29801 & India \\
\hline MZ292134 & Raval,J., et al. & $2021-05-26$ & B.1.36.8 & Severe acute respiratory s... & ssRNA(+) & 29801 & India \\
\hline MZ292135 & Savaliya,N., et al. & $2021-05-26$ & B.1.36.8 & Severe acute respiratory s... & $\operatorname{ssRNA}(+)$ & 29801 & India \\
\hline MZ292136 & Patel,Z., et al. & $2021-05-26$ & B.1.36.8 & Severe acute respiratory s... & $\operatorname{ssRNA}(+)$ & 29801 & India \\
\hline
\end{tabular}

\begin{tabular}{|c|c|c|c|c|c|c|c|c|}
\hline$\square$ & Accession $\triangleq$ & Submitters $=$ & Release Date & Pangolin $=$ & Species $\approx$ & Molecule type $=$ & Length $\Rightarrow$ & Geo Location $=$ \\
\hline$\square$ & $\underline{\text { MZ292137 }}$ & Sharma,S., et al. & $2021-05-26$ & B.1.36 & Severe acute respiratory s... & ssRNA(+) & 29801 & India \\
\hline$\square$ & $\underline{\text { MZ292138 }}$ & Soni,T., et al. & $2021-05-26$ & B.1.1.7 & Severe acute respiratory s... & ssRNA(+) & 29790 & India \\
\hline$\square$ & MZ292145 & Saiyed,Z., et al. & $2021-05-26$ & B.1.36 & Severe acute respiratory s... & $\operatorname{ssRNA}(+)$ & 29801 & India \\
\hline$\square$ & MZ292146 & Pandit,R., et al. & $2021-05-26$ & B.1.1 & Severe acute respiratory s... & $\operatorname{ssRNA}(+)$ & 29801 & India \\
\hline$\square$ & MZ292147 & Patel,Z., et al. & $2021-05-26$ & B.1.1 & Severe acute respiratory s... & $\operatorname{ssRNA}(+)$ & 29801 & India \\
\hline$\square$ & $\underline{\text { MZ292148 }}$ & Savaliya,N., et al. & $2021-05-26$ & B.1.1.306 & Severe acute respiratory s... & $\operatorname{ssRNA}(+)$ & 29801 & India \\
\hline$\square$ & $\underline{\text { MZ292150 }}$ & Soni,T., et al. & $2021-05-26$ & B.1.36 & Severe acute respiratory s... & ssRNA(+) & 29801 & India \\
\hline$\square$ & MZ292151 & Kumar,D., et al. & $2021-05-26$ & B.1.36 & Severe acute respiratory s... & ssRNA(+) & 29801 & India \\
\hline$\square$ & $\underline{\text { MZ292152 }}$ & Pandit,R., et al. & $2021-05-26$ & B.1.36 & Severe acute respiratory s... & $\operatorname{ssRNA}(+)$ & 29788 & India \\
\hline 0 & MZ292153 & Saiyed,Z., et al. & $2021-05-26$ & B.1.36 & Severe acute respiratory s... & $\operatorname{ssRNA}(+)$ & 29801 & India \\
\hline
\end{tabular}




\begin{tabular}{|c|c|c|c|c|c|c|c|c|}
\hline$\square$ & Accession $\Rightarrow$ & Submitters $=$ & Release Date $\triangleq$ & Pangolin $=$ & Species $\Rightarrow$ & Molecule type $\approx$ & Length $\Rightarrow$ & Geo Location = \\
\hline$\square$ & $\underline{\text { MZ292154 }}$ & Sharma,S., et al. & $2021-05-26$ & B.1.36.8 & Severe acute respiratory s... & $\operatorname{ssRNA}(+)$ & 29801 & India \\
\hline$\square$ & $\underline{M Z 292155}$ & Raval,J., et al. & $2021-05-26$ & B.1.36.17 & Severe acute respiratory s... & $\operatorname{ssRNA}(+)$ & 29788 & India \\
\hline$\square$ & $\underline{M Z 292157}$ & Savaliya,N., et al. & $2021-05-26$ & B.1.1 & Severe acute respiratory s... & ssRNA $(+)$ & 29801 & India \\
\hline$\square$ & MZ292158 & Patel,Z., et al. & 2021-05-26 & B.1.1 & Severe acute respiratory s... & $\operatorname{ssRNA}(+)$ & 29801 & India \\
\hline
\end{tabular}

\section{E. Newspaper and Media Reports - all significant relevant coverage}

Use Google Maps if need be to locate the suburbs and regions identified in Melbourne, Victoria, Australia. The main suburbs and areas are Wollert, Whittlesea, Altona North, North Melbourne and Reservoir. Other specific details are in the media reports, although text of key articles is included here.

\section{a. COVID-19 PCR fragments in waste-water catchments during April 2021}

- "Two new wastewater COVID-19 viral fragment detections in Daylesford and Benalla "Government advice from early April 2021

https://www.dhhs.vic.gov.au/wastewater-testing-covid-19

\section{Advice:}

"Viral fragments of COVID-19 have been detected in wastewater samples recently taken from the inlet to wastewater treatment plants at Daylesford and Benalla.

This follows the detection of viral fragments in Moonee Ponds Main and Ringwood South Branch sewer catchments announced earlier this week.

Given the prolonged period of no community transmission in Victoria and absence of local cases in these areas, these are most likely due to a person or people who are not infectious but are shedding the virus.

Victoria's wastewater testing program is designed to provide early warning of COVID-19, and the possibility that someone is in the early phase of the virus cannot be ruled out.

People who live in or have visited the Daylesford area from 10 to 12 April, or the Benalla area from 10 to 15 April, should monitor for symptoms of COVID-19 and get tested if any develop. "

- The Australian online 29.4.21 at 9.45PM by Remy Varga 3 hours ago posted at 6.30 PM

\section{Hundreds told to isolate in Melbourne}

Brief:

Hundreds of people in Melbourne's west and northwest have been asked to isolate after "strong" coronavirus fragments were detected in waste water.

A total of 246 people had been contacted as a precaution after a positive case travelled from Western Australia, A Victorian Health Department spokesperson said on Thursday.

"This additional action is being taken due to the strength of the wastewater detection and because a known positive COVID-19 case, from flight QF778, has been in Victoria in the past 14 days," the spokesperson said. "The 246 people who have been contacted today include four primary close contacts of that case and 242 recently returned red and orange zone travel permit holders.

"All of these primary close contacts have recently been tested and have returned negative results. All of the 246 people are being asked to test again out of an abundance of caution." 
And it is region wide in arc from West to North and some in east. The official waste water detection methods at: https://www.dhhs.vic.gov.au/wastewater-testing-covid-19

“New Detections:

Northwestern suburbs

April 20-27: Glenroy, Hadfield, Oak Park, Pascoe Vale

April 10-15 and 20-26 (repeat detections): Benalla

Western suburbs

April 20-27: Altona, Altona North, Brooklyn, Newport, South Kingsville, Williamstown, Williamstown North Northern suburbs

April 20-27: Briar Hill, Bundoora, Diamond Creek, Greensborough, Lower Plenty, Macleod, Mill Park, Montmorency, Plenty, South Morang, St Helena, Viewbank, Watsonia, Watsonia North, Yallambie, Yarrambat Outer eastern suburbs

April 20-26: Chirnside Park, Coldstream, Kalorama, Lilydale, Montrose, Mooroolbark, Mount Dandenong, Mount Evelyn, Olinda, Yarra Glen, Yering

Active detections

\section{Western suburbs catchment}

April 18-26: Persons visiting or residing in Albanvale, Burnside, Burnside Heights, Cairnlea, Caroline Springs, Deer Park, Delahey, Hillside (Melton), Keilor Downs, Kings Park, Plumpton, Ravenhall, Sydenham, Taylors Hill or Taylors Lakes.

\section{Northwestern suburbs catchment}

April 18-26: Persons visiting or residing in Avondale Heights, Calder Park, Hillside (Melton), Kealba, Keilor, Keilor Downs, Keilor East, Keilor Lodge, Keilor North, Keilor Park, Sydenham or Taylors Lakes.

\section{Eastern suburbs catchment}

April 20-24: Persons visiting or residing in Balwyn, Balwyn North, Blackburn, Blackburn North, Box Hill, Box Hill North, Bulleen, Doncaster, Doncaster East, Donvale, Mitcham, Mont Albert, Mont Albert North, Nunawading or Templestowe Lower.

\section{Outer northern suburbs catchment}

April 17-22: Persons visiting or residing in Epping, South Morang or Wollert.

\section{Comment:}

Given the wide spread Melbourne and regions "waste water" detections ( which would be open to the air, that there have been in-falls with all that pre-winter rain recently early April. Officials are trying to locate source to to infected travellers. But the wide spread nature, the large dilution factors and the "strong positive PCR " detections suggest a region wide in-fall of at least $1000 \mathrm{Km}^{2}$. But no reported community transmissions or mystery cases at this stage, first is "Wollert Man" on May 11.

- Herald-Sun Sunday 6 June 2021 by Laura Placella p.9 “ Covid found in suburbs’ sewage’.

\section{b. Wollert Man}

- In The Australian online 25.5.21

\section{Melbourne's May Cluster as 25.5.21}

May 4: Man in his 30s returns to his Wollert home, on Melbourne's northern outskirts, having contracted coronavirus in an Adelaide quarantine hotel.

May 6-9: The man is believed to have been infectious during this period, having developed symptoms on May 8, and got tested on May 10. His exposure sites during his infectious period were listed as the Epping 
Woolworths, a CBD restaurant, Friday night trains between Craigieburn and the city which were packed with footy crowds, an Indian spice shop in Epping, and a warehouse in Altona North.

May 11: The Wollert man's case becomes public. No further cases are identified among his three household contacts and more than 100 other close contacts.

May 21: Victoria's Health Department reveals it incorrectly listed Epping Woolworths as an exposure site for the Wollert man, due to electronic banking records and the supermarket's proximity to the Indian spice shop the man also visited. In fact the man visited Woolworths Epping North. The department also confirms it has detected strong positive results for coronavirus in sewage from the Wollert and Epping areas. All staff at the Epping North Woolworths have since tested negative.

May 24: Four family members spread across three households test positive for coronavirus. All live in the Whittlesea local government area, which takes in Wollert and Epping. Case One of the four is a man in his 30s, with a man and a woman in their 70s and a preschool aged child also infected. A list of exposure sites for the four, for dates spanning May 19 to 23, includes the Epping North Woolworths, a swim school Bundoora, Victoria's third-largest shopping centre Highpoint in the western suburb of Maribyrnong, a stadium in Brunswick, a service station and soccer field in Reservoir, and several other shops and food outlets in Epping and Epping North.

May 25: A fifth case is confirmed in a man in his 60s, who had a business appointment with Case One on May 18. Health authorities say the fifth case developed symptoms earlier than the other four cases, who are believed to have caught the virus via him. Genomic sequencing confirms the five latest cases are closely linked to that of the Wollert man, but no direct links have yet been established.

- How Wollert Man may have caught B.1.617.1 at Adelaide Quarantine hotel

The Australian May 282021 9.33AM by Stephen Lunn “ The 18-second Adelaide hotel Covid-19 breach that brought misery and despair to seven million Victorians”. Full text is

"It was the sliding doors moment that left nearly seven million Victorians facing another soul-crushing lockdown.

Just 18 seconds in duration. On May 3 in the Playford Hotel in Adelaide's CBD, the door to the room of a man known as Case A was opened for a couple of seconds. Just enough time for the 30 -something to collect a meal placed outside.

Case A, as SA Health has dubbed him in its investigation into how the virus spread inside the hotel, was near the end of his 14-day quarantine after returning from India. He was tested for Covid-19 on day one, five and 13, returning a negative result each time.

But unfortunately for Case A, and now for Victoria, he was in a room adjacent to Case B.

In what should have been a red flag given previous incidents of hotel quarantine infections, their rooms were at the end of a corridor.

SA Health's report released late Wednesday revealed that twice on May 3 Case A opened his door to collect a meal, but so too did Case B. He hadn't been diagnosed with Covid at the time, only starting to show symptoms

"On one occasion, Case B opened his room door to collect his meal, then 18 seconds later Case A opened his door to collect his meal," the report says. "This was during the time Case B was infectious but prior to staff knowing his positive Covid-19 status. A similar situation was observed again on the same day with a time lapse of less than 12 minutes. 
"Case B opening their door could have resulted in potentially contaminated corridor air either directly exposing Case A or forcing contaminated air into his room, particularly given Case B's room was situated at the end of a corridor and the intervening time period may not have allowed exchange of fresh air to have occurred despite adequate ventilation levels in the corridor."

It was potentially the 18-second window that saw Covid-19 pass from one hotel room to another, then, as we now know from genomic testing, to a northern Melbourne suburb, then across the city into workplaces, nightclubs and football stadiums.

\section{Spreading far and wide}

Since then, infected people have spent time in Bendigo and in Cohuna near the NSW border. A netball match in Cohuna against a team from the Riverina in NSW has led to people across the border being urged to get tested. More than 100 people linked to exposure sites who have since returned to South Australia and a number in Western Australia are being urged to isolate and test.

What's it all mean? Small businesses smashed. Again. Melbourne's CBD ghostly quiet. Again. Families denied access to loved ones in hospitals and nursing homes. Again. Parents dealing with children's remote learning. Again. Anxiety and stress. Again.

Part of the anxiety is the unknown. Though Victorian Acting Premier James Merlino and Health Minister Martin Foley say they take some comfort in that the 26 Covid cases identified so far are genomically linked, two concerns stand out.

\section{Filling in the gaps}

First is a gap in the chain of transmission. Case A was released from hotel quarantine on May 4 and returned to the north Melbourne suburb of Wollert. He felt unwell and tested for the virus on May 8, receiving confirmation of his positive status on May 11.

While there has been a genomic link established between Case A and the new Covid cases in Melbourne, no direct connection has been identified. Only the most general geographic link — that Case A and the so-called "index case" in the new Melbourne cluster live nearby in the Whittlesea area - has been established.

Second is the pace of the spread. Consider this. The index case, labelled by Victorian health authorities as Case 5 (the fifth positive case identified in this outbreak), is a man in his $60 \mathrm{~s}$. He tested positive on Tuesday, but was believed to be infectious since May 15 and had symptoms on May 17.

He had a business meeting with Case 1, a man in his 30s, on May 18. Case 1 tested positive on Monday, as did three of his relatives, including a preschool-aged child.

Four of Case 5's relatives have also tested positive, one of whom works in Stratton Finance, a large financial firm in Port Melbourne. Five work colleagues have tested positive.

It is understood one of those five spent much of last Saturday evening hopping between nightclubs in the Melbourne party zone of Prahran and South Yarra.

Others among the cases identified so far had been to two AFL games. The area of the MCG named as an exposure site following Sunday's Collingwood-Port Adelaide game included the Port cheer squad.

In short, since Case 1 was identified as Covid-positive on Monday, 14,000 primary and secondary contacts have been identified by contact tracers. And more than 150 potential exposure sites, public and private, have been found.

\section{Question of quarantine}


Amid the blizzard of numbers is a bleak reminder of Covid's considerable dangers. Of the 26 cases in this cluster, one elderly person is in intensive care. Merlino said the person was "not in a very good way".

Victorians, again the pariahs of the nation, are now wondering if this fourth lockdown could have been avoided.

Certainly the state's chief health officer, Brett Sutton, was blunt when asked on Thursday about the genesis of the outbreak, another case of airborne transmission inside hotel quarantine.

"We have seen it too many times. It happens when doors open in quick succession," he said. "That is something we have tried to mitigate in Victoria as much as possible with filtered air purifiers in corridors. That said, hotels are not the ideal structural environment to keep people (in quarantine)."

\section{c. Whittlesea Cluster}

Above timeline and

- The Australian online 29.5.21 by Rhiannon Down 6 hours ago 4.35 PM

"Complex web of connections behind Covid outbreak"

\section{d. Arcare Facility Cluster, Maidstone}

- Reported on $\mathrm{ABC}$ news online

https://www.abc.net.au/news/2021-05-30/victoria-records-five-new-local-covid-cases/100176658

- The Australian online May 302021 post ed 11.20 PM “Coronavirus: mystery case hits lockdown plan" by Rebecca Urban, Remy Varga, ( also reported Herald-Sun June 12021 p.4-5).

The mystery case of a Melbourne aged care employee who worked for two days while potentially infectious with Covid-19 has emerged as a priority for contact tracers and a risk to Victoria ending its seven-day lockdown.

The healthcare worker, a woman aged in her 50s who tested positive on Saturday, has no known link to other cases in the state's latest outbreak, which has spread to 40 after five new infections emerged on Sunday.

Victoria's Covid-19 response commander Jeroen Weimar said the aged care case was an "extreme concern" due to both the work setting and unknown acquisition source.

Contact tracers were working hard to identify potential exposures within the facility but also the wider community, he said.

"This is the first mystery case we have seen in this particular outbreak," Mr Weimar said.

"I am concerned that at this point in time we don't have an original acquisition source.

"It is our most vulnerable and sensitive setting ... and that is why we have put such an important response into this since late last night."

Acting Premier James Merlino described the case as a "very, very serious matter" and declined to be drawn on whether lockdown restrictions would be eased on Friday as initially scheduled.

It was a day-by-day proposition, he warned.

"We are three days into a seven-day lockdown," Mr Merlino said. 
“Today we're talking about a mystery case. Today we're talking about aged care.

“There's a lot of work to do."

Mr Merlino said health officials were working at an "unbelievable rate" and a majority of more than 4000 primary close contacts across all exposure sites had been tested, with about 70 per cent returning negative tests so far.

More than 45,000 Victorians were tested on Saturday. A testing blitz was under way on Sunday at Arcare Aged Care Maidstone, which bills itself as a "five-star" private facility in Melbourne's west, where residents have now been subjected to hard lockdown and confined to their rooms.

Staff were provided with upgraded "tier three" personal protection equipment and additional cleaners were also deployed to the centre, which has recorded seven positive cases throughout the pandemic - all of which were employees - but no deaths

- The Australian online by Angelica Snowden 6 June 2021 posted 12.30PM “ Two more cases confirmed in Melbourne aged care"

- The Australian online May 312021 posted 9.52 AM by Rachel Baxendale "Second Melbourne aged care worker test positive"

Brief:

"A second staff member at a second Victorian aged care facility has tested positive for coronavirus.

BlueCross Western Gardens in the western Melbourne suburb of Sunshine have confirmed a staff member tested negative on their last day of work, before returning a positive result on Sunday night.

The news comes after a staff member at the Arcare facility in Maidstone, also in Melbourne's west, tested positive on Saturday, with at least one Arcare resident since infected.

Contact tracers are yet to link the Maidstone case to the Whittlesea cluster of at least 40 coronavirus cases.

At least two other aged care facilities have gone into lockdown after staff worked across multiple centres."

\section{e. Delta Cluster variant, North Melbourne}

- The Australian online 4 June 2021 at 9.30PM by Rachel Baxendale posted at 8.45 PM "Breakdown cluster sparks hunt for source"

Health authorities in multiple states are checking genomic sequencing data for all known Delta variant cases of coronavirus in Australia, as mystery surrounds the origins of a cluster of seven cases linked to a West Melbourne family who spent six days in NSW.

The revelation that the seven cases are unrelated to Melbourne's other community-acquired cases came amid confusion over the Andrews government's handling of two false positive cases revealed late on Thursday, which contributed to Wednesday's decision to extend Melbourne's lockdown.

Business groups and the state opposition called for the lockdown to end as soon as possible, as Victoria recorded four new cases, all of which were in quarantine and close contacts of existing cases.

Of 67 community-acquired cases diagnosed in Victoria since a man in his 30s caught the virus in an Adelaide quarantine hotel and returned to the outer northern Melbourne suburb of Wollert on May 4, 54 are linked to the 
main Whittlesea cluster across Melbourne's northern suburbs and an associated workplace in Port Melbourne, while five are associated with a cluster linked to the Arcare aged-care facility in Maidstone in Melbourne's west.

- The Australian online as 4 June 2021 posted 2.39PM PM by Rachel Baxendale "Timeline: what we know about west Melbourne outbreak"

\section{May 19-24:}

- Family of four from West Melbourne begin the first day of their holiday, driving from Melbourne to the Green Patch Campground at Booderee National Park near Jervis Bay on the NSW South Coast.

- It's not known where they stopped in Victoria, but their NSW stops include a cafe, craft centre and antique shop in Gundagai and the Shell Coles Express Big Merino service station in Goulburn.

- On Friday May 21 they visited a cafe and bric-a-brac store in Huskisson, and a Coles in Vincentia, and on Sunday May 23 they visited a cafe in Hyams Beach and revisited the Vincentia Coles.

- On Monday May 24 they travelled back to Melbourne, via a bakery and the Big Merino service station in Goulburn, as well as BP truck stops in Glenrowan, Euroa and Wallan in the Victorian side of the border.

\section{May 25:}

- Adult male family member develops symptoms.

- He works at GTA Consultants, on Levels 24 \& 25 of 55 Collins St in Melbourne on this day.

- Authorities in NSW and Victoria initially consider the man and his family to have likely been infectious from May 23, two days before the onset of symptoms, but extend the period back to May 19 when other family members later test positive.

\section{May 26-31:}

- Family members visit a range of sites in Melbourne's CBD and inner north and west while likely infectious, including North Melbourne Primary School, Joeys Scouts Carlton, Flagstaff Gardens, Officeworks QV, Coles Spencer St, male public toilets at 225 Bourke St, and Costco Docklands.

\section{Tuesday, June 1:}

- Authorities in NSW and Victoria confirm the adult male family member has tested positive for coronavirus. Initially he is assumed to be part of the wider Melbourne cluster linked to Adelaide hotel quarantine, pending confirmation from genomic sequencing.

\section{Wednesday, June 2:}

Three more family members test positive, including an adult female and two children.

\section{Friday, June 4:}

- Positive results are received for two adults and a child, understood to be a Grade Five student at North Melbourne Primary School. It's believed the Grade Five caught the virus from a classmate, who is a member of the West Melbourne family.

- An inconclusive result is received for a second child.

- There are now seven confirmed positive cases linked to the West Melbourne cluster. 
- Chief health officer Brett Sutton reveals genomic sequencing has found the family have the Indian B.1.617.2 or Delta strain of the virus, as opposed to the Indian B.1.617.1 Kappa strain found in members of Melbourne's other current clusters.

- While the Delta strain has been detected in hotel quarantine cases up and down Australia's eastern seaboard, none of these cases is a genetic match for the virus found in the West Melbourne family.

- Sutton says it is possible, given the timing of the onset of symptoms, that the family caught the virus in NSW.

- The Australian online 5 June 2021 posted $12.40 \mathrm{PM}$ by Rhiannon Down "Delta variant cluster now at nine cases"

Victorian testing commander Jeroen Weimar has confirmed that two of today's five new Covid-19 cases are part of a cluster of the Delta variant.

Mr Weimar confirmed the cluster, which was first detected in one family from West Melbourne who spent six days in NSW last month, had grown to nine cases.

"Then of course, our new cluster, the Delta variant cluster that we are most concerned about," he said.

"Nine active cases, that is an increase of two from yesterday.

Mr Weimar said one of the cases was in a child belonging to the second family in the cluster, who have already had one child test positive.

"One of those is a second child of the second family," he said.

"So we have two families of four, both active with Covid, and then one where the primary close contact, a workplace colleague of the first case that was identified a few days ago.

"We have identified some exposure size for that individual."

- The Australian online 8 June 2021 by Rachel Baxendale posted 9.30 PM

"Delta dawned from yet another hotel breach"

Link to such a breach is tenuous and unclear see https://www.abc.net.au/news/2021-06-10/victoria-new-covid-cases-melbourne-lockdownrestrictions $/ 100203632$

\section{f. Reservoir Cluster, in northern suburbs}

- Outline on $\mathrm{ABC}$ news at https://www.abc.net.au/news/2021-06-10/victoria-new-covid-cases-melbourne-lockdownrestrictions $/ 100203632$

- The Australian online 10 June 2021 by Rachel Baxendale posted at 6.12PM "Household cluster sounds new alarm" 
A new mystery cluster of four cases in a household in Melbourne's north has spooked Victorian health authorities, prompting a backflip on plans to ease rules governing the wearing of masks outdoors.

The about-face came despite an admission from Victoria's Covid logistics chief, Jeroen Weimar, that there has been no evidence of outdoor transmission of the virus this year.

Victoria's health department is also investigating a possible link between a coronavirus-positive couple who left the outer northwestern suburb of Melton on June 1 and travelled through NSW to Queensland, and a shopping centre in Melbourne's outer north visited by nine other cases.

Victoria's latest cases include a man in his 80 s, a woman in her 70 s, a man in his 50 s and a man in his 20 s who all live in the same household in Reservoir in Melbourne's northern suburbs.

How they caught the virus remained a mystery on Thursday, with the man in his 80 s the first to return a positive test result on Wednesday, followed by the others. Victoria's health department said authorities had also tested "a number of high-risk primary close contacts of the cases outside of the household" and all had returned negative results, although no detail was provided on the nature of the "high-risk".

Exposure sites visited by household members included a shopping centre in Bundoora and a service station in Thomastown on Monday, and a grocery store in Reservoir and Bunnings in Thomastown on Tuesday.

Ahead of an easing of Melbourne's lockdown on Thursday night, Acting Premier James Merlino warned Victoria remained on "high alert" for undetected community transmission.

"I can confirm the easing of restrictions that we announced yesterday will proceed as planned from $11.59 \mathrm{pm}$ tonight with one small exception for Melbourne: masks will continue to be required to be worn outdoors in all circumstances," he said.

Mr Weimar was asked if there had been any recent examples of coronavirus being transmitted outdoors in Victoria. "No. We have no evidence that we have seen in this ... outbreak or the most recent ones, of outdoor transmission," he conceded.

Acting deputy chief health officer Allen Cheng said instances of outdoor transmission had been confirmed during Victoria's second wave of coronavirus last year.

"They're not very common but they do occur. When there are active cases in the community, I think it's a small thing to ask for people to continue to wear masks at all times when outside of home," Professor Cheng said.

He said Victoria's public health team estimated "perhaps 5 per cent" of cases in the second wave had been transmitted outdoors "but, again, it can be very difficult to tell".

More than 24 hours after Queensland broke news of a positive test from a traveller from Victoria, and NSW issued a list of sites visited in that state, Victoria was yet to release details of any exposure sites.

The state's health department said a contact tracing interview was ongoing late on Thursday.

The first member of the couple to test positive, a 44-year-old woman, is believed to have been infectious when they left home on June 1 and developed symptoms on June 3.

Contact tracers are investigating a potential link to the Craigieburn Central shopping centre, where one of the couple checked in on May 23, given nine other cases have visited the site during the current outbreak. 


\section{g. Summary of all Mysteries in The Australian 13 June 2021}

The Australian Online 13.6.21 Rachel Baxendale posted at 4.30PM

\section{The six missing links in Victoria's Covid clusters}

There have now been six coronavirus cases among Victoria's two current outbreaks where authorities have been unable to identify a source of infection, including three this week:

1. The first mystery case emerged on May 24. While the initial May 24 case was linked back to at least one prior case, the path of transmission has not been established between what has become known as the Whittlesea cluster and the genomically linked Kappa strain case of a man who returned to the northern suburb of Wollert on May 4 after contracting coronavirus in an Adelaide quarantine hotel. The Port Melbourne cluster is a directly linked offshoot of the Whittlesea cluster, sparked by a close contact who worked at Stratton Finance in Port Melbourne. The Whittlesea cluster and the Port Melbourne cluster each comprise 32 cases, with an overlap of one case which fits into both clusters.

2. The Arcare cluster of 11 cases, the first of which emerged on May 31, is genomically linked to the Kappa strain outbreak. The direct source of acquisition has not been identified.

3. The West Melbourne outbreak of 15 cases are linked to a genomically distinct Delta cluster sparked by a man in his 40s who arrived in Melbourne from Sri Lanka on May 8. The direct link has not been established between the man and the cluster - which comprises two families and their close contacts and first emerged on June 1.

4. Two cases identified on Wednesday and Thursday in a couple from Melton, in Melbourne's outer northwest who tested positive in Queensland. While the cases have been genomically linked to the Kappa outbreak, the direct source has not been identified.

5. Thursday's new case in four members of a Reservoir household in Melbourne's north. While this case has been genomically linked to the Kappa outbreak, the direct source has not been identified. Exposure sites include locations is Reservoir, Thomastown, Epping and Bundoora, all in the northern suburbs.

6. Saturday's single new case in a City of Melbourne resident. Victorian Covid-19 logistics chief Jeroen Weimar said on Sunday authorities were expecting to receive genomic sequencing of the case late on Sunday night or on Monday. The genomic sequencing is expected to confirm whether or not the case is linked to either current Melbourne cluster. "We're seeing a number of close linkages we're exploring between that particular case and other parts of the Kappa outbreak," Mr Weimar said. Exposure sites for the case include locations in Docklands, Southbank, Thornbury, Reservoir and North Geelong.

Note : Through to June 192021 number increased a little in each cluster by P-to-P spreads but all clusters were unlinked to each other - missing links not definitively found as documented in this paper. 
Edward J. Steele (2021) COVID-19 Sudden Outbreak of Mystery Case Transmissions in Victoria, Australia, May-June 2021: Strong Evidence of Tropospheric Transport of Human Passaged Infective Virions from the Indian Epidemic

\section{F. Indian 'delta' variant (B.1.617.2) now going global as June 192021}

As this paper was being submitted it seems that the southern Chinese city of Guangzhou may be engaged in a sudden tropospheric strike of variants from India.

https:/www.news.com.au/world/coronavirus/global/china-hit-by-devastating-covid-outbreak-in-the-cityof-guangzhou/news-story/42a8ac41bd27d3a24620e1888671e08e

Further many other Northern Hemisphere countries (Russia, UK, USA) are also reporting the sudden spread of the Indian delta variant on real population wide scale.

https://www.news.com.au/world/coronavirus/global/highly-infectious-delta-variant-quickly-taking-overthe-world/news-story/5325efa0d41c14856a728d92ee597a91 